\title{
State of the art review on physiochemical and engineering characteristics of fly ash and its applications
}

\author{
Amit Kumar Ram ${ }^{1} \cdot$ Supriya Mohanty ${ }^{1}$
}

Received: 7 January 2021 / Accepted: 17 January 2022

(c) The Author(s) 2022

\begin{abstract}
The focus of this study is to critically review the physiochemical and engineering properties of the fly ash and its applications in various fields. The utilization of fly ash has become a widespread area, but the amount of utilization is still a serious issue. It has many beneficial qualities (such as pozzolanic property, fineness, spherical shape, lightweight, etc.), which enhance its properties and make it suitable for its utilization as a new construction material. For the bulk utilization of fly ash, it should be employed in the areas independent of any other parameters. So that, the disposal problem can be reduced significantly. The knowledge of its physiochemical characteristic helps in the judgment of appropriate fly ash for any particular type of work. Fly ash can be utilized in other areas such as asphalt concrete, geopolymer concrete, ground improvement, agricultural sector, roller compacted concrete, brick, etc. that will reduce the existing ashes, and also the disposal problem can be solved appreciably. The implementation of fly ash must be avoided below the natural ground water level and below $4{ }^{\circ} \mathrm{C}$ temperature conditions.
\end{abstract}

Keywords Fly ash $\cdot$ Chemical property $\cdot$ Engineering property $\cdot$ Construction material

\section{Introduction}

Coal is the most affordable/abundant source of natural resource for the electricity production in India. Anthracite, bituminous, sub-bituminous, and lignite are the four kinds of coal yield in India. Out of the above mentioned coal type, bituminous coal is extensively used for the generation of electricity. The eastern and southern geographical areas of India have a considerable amount of reserved coal. Jharkhand and Odisha account for more than half of the reserved coal, i.e., $26.06 \%$ and $24.86 \%$, respectively, among all states with coal deposits (Energy Statistics - MOSPI 2019). The distinct sources of electricity generation in India are coal/lignite (56.4\%), Gas (7\%), Diesel (0.18\%), Nuclear (1.9\%), Hydro (12.75\%), and Renewable energy resources (21.80\%) (Ministry of Power-CAE 2019). Coal is one of the major sources of electricity production, which is responsible for the higher coal combustion residues.

Supriya Mohanty

supriya.civ@iitbhu.ac.in

1 Department of Civil Engineering, Indian Institute of Technology (Banaras Hindu University), Varanasi 221005, India
The production of coal/lignite in the year 2017-2018 was observed to be 721.66 million tonnes (Energy Statistics - MOSPI 2019). These coals are deprived in nature, having an average ash content of 30\%-50\% (Chikkatur et al. 2009). That means $40 \%$ ash content coal may result in the generation of nearly 288.66 million tonnes of coal combustion residues, leading to an expectation of 1000 million tonnes in the year 2031-2032 (Coal Ash Institute of India).

Fly ash covers 70\% - 80\% (Sadasivan and Negi 1991; Singh et al. 2012) of the coal combustion residue, i.e., nearly 216.5 million tonnes. The generation and utilization percentage of fly ash for the past two decades can be seen in Fig. 1. Also, the gap between the generation and utilization has been decreasing with the increase in time. Coal that shows high ash content normally has less calorific value (Roy 1940). Fly ash has many beneficial qualities, hence, it is critical to focus on the extensive investigations for its potential applications in various fields.

Fly ash and bottom ash are the two types of coal combustion leftovers that are blended and disposed of directly into the ponds/lagoons in both dry (Mound ash) and wet (Pond ash) conditions (IS 3812 - Part 2, 2013). Bottom ashes are collected from the lower part of the boiler whereas fly ashes are extracted from the flue gases using an electrostatic 


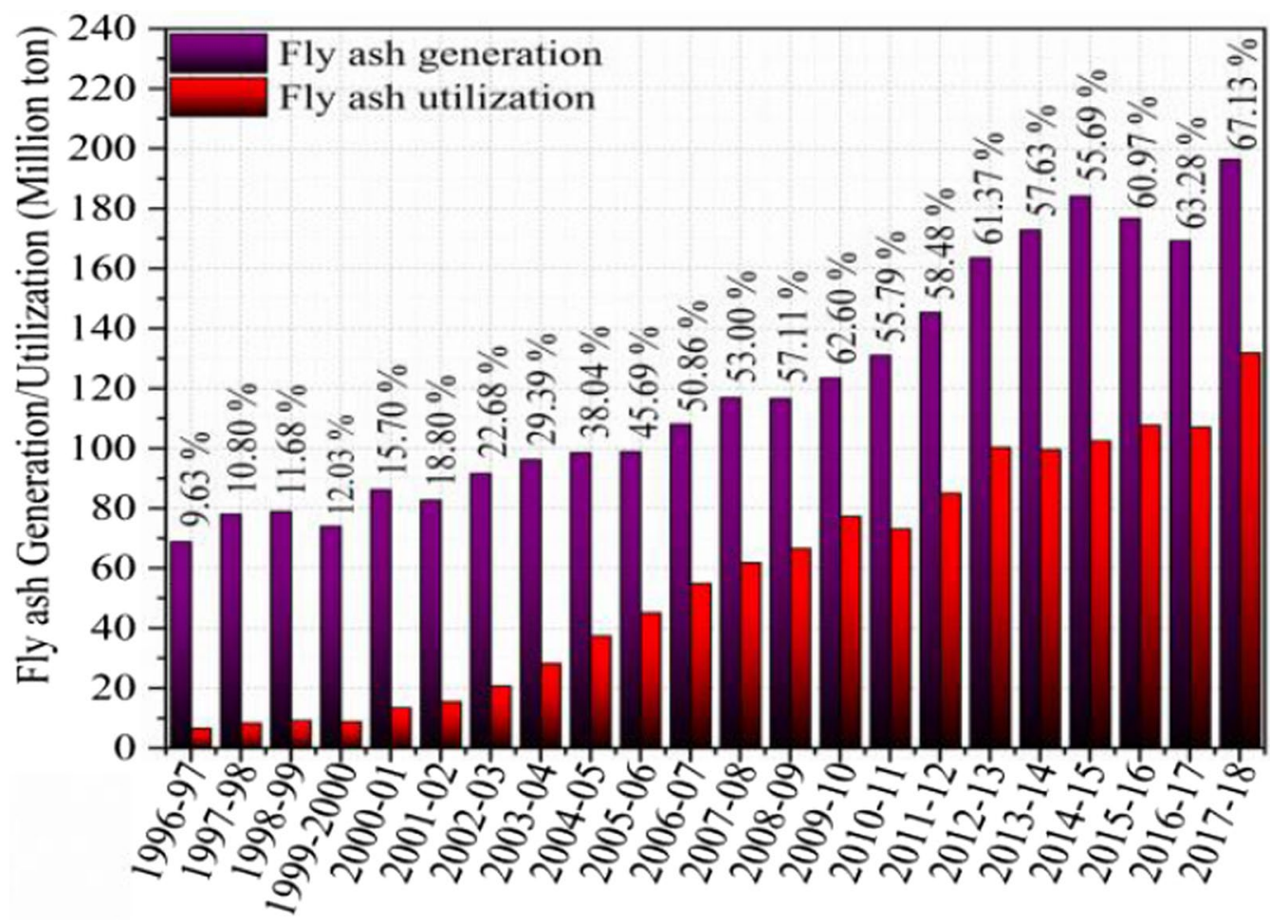

Fig. 1 Demonstration of the generation and the utilization of fly ash in India

precipitator (White 1977; Jędrusik and Świerczok 2011; Karunakaran et al. 2019). The electrostatic precipitator is responsible for capturing almost $77 \%$ of the fly ash or even higher (Page et al. 1979). In addition, the electrostatic precipitator has a removal efficiency of $95.0 \%-99.8 \%$ for a finer fraction of coal ash (Bhanarkar et al. 2008). It consists of four to six hoppers (also called field) and more the number of fields results in a higher degree of fineness (Trivedi and Sud 2004; Chengfeng et al. 2005). Therefore, fly ashes collected at the initial stage are generally coarser than that of the later stage of electrostatic precipitators (IS 3812 - Part 2 , 2013). The physical and chemical properties of the fly ash are substantially dependent on the types of coal used, burning temperature/conditions, and collection process (Thompson 2008). Fly ash has pozzolanic property by virtue of which it gets hardened or strengthen when comes in contact with water and reacts with calcium hydroxides to form bond making compounds. There are two types of pozzolanic materials like natural material (pyroclastic rock, tuffs, diatomaceous earth) and artificial material (fly ash, rice husk ash, silica fume, burned clay \& shale) (McCarthy and Dyer 2019). The main compound presents in both artificial and natural materials are silica and alumina.

Fly ash has been classified into different categories based on $\mathrm{pH}$, class, and chemical compositions in order to conveniently use it in any suitable work. Kocuvan (1979) was the pioneer of the fly ash classification, who employed a size of particles and ratios of $\mathrm{SiO}_{2}, \mathrm{Al}_{2} \mathrm{O}_{3}, \mathrm{Fe}_{2} \mathrm{O}_{3}, \mathrm{CaO}, \mathrm{SO}_{3}$, and $\mathrm{MgO}$, to classify the fly ash for their application in concrete. A triangular classification system has been proposed by Roy et al. (1991) on chemical compositions having ends representing $\mathrm{SiO}_{2}+\mathrm{Al}_{2} \mathrm{O}_{3}+\mathrm{TiO}_{2}, \mathrm{CaO}+\mathrm{MgO}+\mathrm{Na}_{2} \mathrm{O}+\mathrm{K}_{2} \mathrm{O}$ and $\mathrm{Fe}_{2} \mathrm{O}_{3}+\mathrm{MnO}+\mathrm{SO}_{3}+\mathrm{P}_{2} \mathrm{O}_{5}$. This system expressed fly ash in 7 chemical names and further, it was modified by Roy et al. (1982). The fly ash having a $\mathrm{pH}$ in the range of $1.2-7,8-9$, and 11-13 are classified as acidic ash, mildly alkaline ash, and strongly alkaline ash, respectively (Kolbe et al. 2011). Class $\mathrm{C}$ defines the class of fly ash having more than $50 \%$ of the sum of silica, alumina, and iron oxides whereas this sum account for greater than $70 \%$ in the case of class $\mathrm{F}$ fly ash (Mehta 1989; ASTM C618-03 2003). The burning of high quality coal (anthracite and bituminous coal) results in the generation of low calcium fly ash; on the contrary, the combustion of low quality coal produces high calcium fly ash (Zahedi and Rajabipour 2019). Based on the proportion of free calcium oxides, fly ash is divided into inactive, slightly active, active, and very active fly ash, indicating the amount of free calcium oxides less than $3.5 \%, 3.5 \%$ to $7 \%$, $7 \%$ to $14 \%$, and greater than $14 \%$, respectively (Vassilev and Vassileva 2007).

Fly ash is fine in nature with a maximum contribution of silt size particles. In general, the size of fly ash ranges from 10-100 $\mu \mathrm{m}$ (Malviya et al. 1999; FHWA-I-03- 019 2003). Geotechnical characterizations of fly ash have been done 
by several authors (Sridharan et al. 1998; Pandian 2013; Kim et al. 2005; Das and Yudhbir 2005; Prakash and Sridharan 2009), in order to determine its physical/engineering properties. Many authors have investigated the behavior of fly ash in concrete considering cubical mortar specimens of size $50 \mathrm{~mm} \times 50 \mathrm{~mm} \times 50 \mathrm{~mm}$ (Tepsri et al. 2018; Chindaprasirt et al. 2013; Zahedi and Rajabipour 2019) and $40 \mathrm{~mm} \times 40 \mathrm{~mm} \times 40 \mathrm{~mm}$ (Li et al. 2012) for the evaluation of its compressive strength. The present review article precisely focuses on the investigation of physical, chemical, pozzolanic property, engineering properties, and application of fly ash as supplementary cementitious material, and construction material in the field of civil engineering. Fly ash has several applications in engineering areas such as the substitute of cement, embankment fill, ground improvement, flowable fill, filler in asphalt pavement, grout, agriculture, and the making of brick/tiles, etc. (Alam and Akhtar 2011; Cao et al. 2008; Ferreira et al. 2003; Pandey et al. 2009; Dhadse et al. 2008; Fatih and Umit 2001; FHWA-IF-03-019 2003; Karasawa et al. 2003). Table 1 represents the mineralogical composition of fly ash in different countries. The glass shows a higher proportion among other minerals whereas mullite shows wide variation among reported countries in Table 1.

\section{Physical characteristics of fly ash}

\subsection{Specific gravity}

The specific gravity of Indian origin fly ash is mostly found to be in the range of 1.9-2.2 (Pandian et al. 1998). Also, the specific gravity of coal ash was varied from 1.6 to 3.1 (McLaren and Digioia 1987; Behr-Andres and Hutzler 1994). The specific gravity of fly ash produced from sub-bituminous and bituminous (high iron) coal are 1.90 and 2.96 respectively (theconstructor.org). The specific gravity of crushed fly ash (425 m passing) is higher than that of uncrushed fly ash, indicating that its specific gravity decreases as the particle size increases. When fly ash, bottom ash, and pond ash are all collected from the same place, fly ash shows higher specific gravity than the other two. It decreases with the rise in temperature of the boiler under operation (Moghal 2017). Iron and carbon content has a larger influence on specific gravity, indicated by an increasing \& decreasing trend with the increase in iron and carbon content, respectively (Cabrera and Gray 1973). This particularly depends on the particle size distribution, coal type, and shape of the particles. The low specific gravity is attributed due to the presence of light hollow spherical (cenospheres) particles and it is an advantageous property as it produces low earth pressure, high workability. The geotechnical properties of the fly ash of about one-third of the total states in India have been tabulated in Table 2. Table 2 indicates that the Indian fly ash has a specific gravity of 2 on an average (approx.), which is in accordance with the previous literatures as illustrated in Fig. 2a. When compared to class $\mathrm{C}$ fly ash, the majority of the fly ash produced in India is of the class F kind, which contains a higher percentage of cenospheres. This is a reason why the class $C$ type fly ash has a higher specific gravity than that of class F fly ash.

\subsection{Grain size distribution}

The shape of the fly ash particles is mostly spherical in nature, having a glass content of transparent impression (Davison et al. 1974). Fly ash has a very broad range of particle sizes and for Indian fly ash, it is $<0.1 \mu \mathrm{m}$ to $>100 \mu \mathrm{m}$ (Kumar and Upadhyay 1983). The usability of fly ash in concrete has been indicated by two significant factors, Arithmetic mean diameter (AMD) and Span (Sarkar et al. 2012; Duan et al. 2017). Span gives an idea about the gradation whether it is well or poorly graded. A lower Span indicates homogeneous/uniform fly ash, which shows a high specific surface area (SSA) (Sarkar et al. 2005). Fly ash having an AMD value of less than $10 \mu \mathrm{m}$ are good for the use in concrete mortar (Tripathy and Mukherjee 1997). The particle size analysis of fly ash evident that it has a higher concentration of silt size particles ( $>60 \%)$, followed by sand ( $>25 \%$ ) and clay (more or less than 5\%) (Chang et al. 1977; Fulekar and Dave 1986; Mishra and Shukla 1986a, b). Similarly, for coal ash, the silt size fraction is higher as compared with sand and clay (Rees and Sidrak 1956; Cope 1962).

The specific surface area is inversely proportional to the size of the particles and has ranged from 1.27 to 0.45 $\mathrm{m}^{2} / \mathrm{g}$ (Schure et al. 1985). The nomenclature of fly ash has been done using the coefficient of uniformity $(\mathrm{Cu})$ and coefficient of curvature $(C \mathrm{c})$ which was calculated from
Table 1 Mineral composition of fly ash in different countries (Values in percent, Source ACAA 2003 \& Malviya et al. 1999)

\begin{tabular}{lccllllc}
\hline Minerals & China & India & USA & UK & Japan & South Africa & Australia \\
\hline Quartz & $2.5-5.1$ & $2-10$ & $0.0-4.0$ & $1.0-6.5$ & $5.4-11.8$ & $10.7-14.1$ & $10.9-8.5$ \\
Mullite & $1.98-25.1$ & $5-15$ & $0.0-16.0$ & $9.0-35.0$ & $8.0-18.0$ & $17.7-25.31$ & $15.4-12.4$ \\
Hematite & $0.9-13$ & $1-3$ & $0.0-8.0$ & 5.0 or Less & - & $0.8-0.16$ & $0.4-0.6$ \\
Magnetite & $1.5-4.6$ & $0.5-3$ & $1.0-30$ & 5.0 or Less & $0.5-5.3$ & 0.1 & $0.4-0.9$ \\
Glass content & $54.4-82$ & $50-90$ & $50-90$ & $50-90$ & $69-84$ & $59-62.1$ & $66.7-78.5$ \\
\hline
\end{tabular}



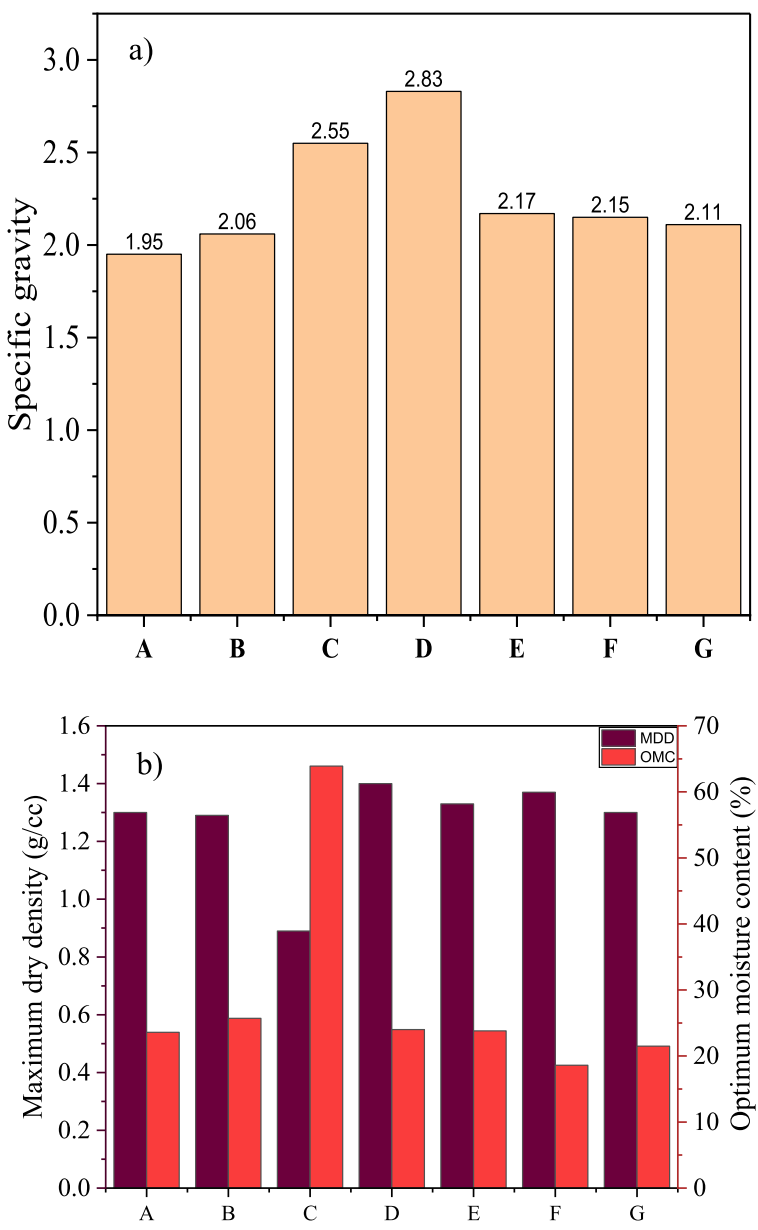

Fig. 2 Illustration of a specific gravity, b maximum dry density, and optimum moisture content of fly ash determined by several authors. (A-Sridharan et al. (1998), B-Sridharan et al. (2001), C-Pandian (2013), D-Moghal and Sivapullaiah (2011-C), E-Moghal and Sivapullaiah (2011-F), F-Kumar et al. (2014a), G-Rajak et al. (2017))

the particle size distribution plot. For Indian fly ash, $\mathrm{Cu}$ and Cc range from 13.3-10.0 and 2.16-0.73, respectively (Sridharan et al. 1998). In particular, fly ash shows the uniform distribution with a higher value of $\mathrm{Cu}$. The disposal of fly ash in slurry form results in a higher fraction of sand size particles at the near end disposal point as compared to the far end disposal point where silt size particle fractions are predominant. The particle size distribution profile of the fractions passing through 75 microns can be done by hydrometer analysis for low calcium fly ash. On the other hand, XR sedimentation, counting of grain by laser particle, and electrolyte resistivity methods are employed for the high calcium fly ash. The inapplicability of hydrometer analysis for high calcium fly ash is associated with the reaction between lime and water, which form cementitious compounds. The general classification of fly ash is silty sand or sandy silt. Another form of coal ash, such as pond ash and bottom ash, are usually found in coarser nature in comparison with the fly ash.

\subsection{Compaction characteristics of fly ash}

Compaction is one of the important geotechnical properties of the fly ash because their knowledge facilitates in proper densification of fly ash in the field. The parameters responsible for the lower dry density are low specific gravity, high content of silt size particle (Raymond 1961), and the presence of cenospheres that has a tendency to absorb appreciable quantities of water (Das and Pakrashi 1990). The shape of the plot between maximum dry density (MDD) versus optimum moisture content (OMC) was found to be the same as that of cohesive soils (Digioia and Nuzzo 1972; Dayal et al. 1989; Singh 1996). The compaction characteristics of coal ash can be plotted in terms of volumetric basis (void ratio vs. volume water content) instead of weight basis since weight is dependent on specific gravity and coal has a wide range of specific gravity (Prashanth et al. 1998; Sridharan et al. 2001). High calcium fly ash has shown higher MDD and lower OMC as compared to the low calcium fly ash (Yudhbir and Honjo 1991). Indian fly ash has low dry density and high moisture content of the order of $0.9-1.3 \mathrm{~g} / \mathrm{cc}$ and $18 \%-38 \%$ respectively (C-Farm). It is essential to densify the fly ash within $95 \%-100 \%$ of MDD when used as fill material of the embankments (ASTM D 698-2000 (1995)). Moreover, it should be compacted below OMC to avoid difficulty in the compaction process. During the compaction, the moisture squeezes out from the compacted surface which in turn reduces the overall moisture below OMC, indicating lower density. The vibratory smooth drum roller and Pneumatic tired drum roller required more than 8 passes for a thickness of $150 \mathrm{~mm}$ (approx.) to achieve 95\% of MDD. Fly ash is a non-plastic material having a flatter compaction plot. Flat shape of compaction plot is associated with the fact that the change in moisture does not influence the dry density. The MDD and OMC of most of the fly ash have been listed in Table 2. It can be concluded that the average MDD and OMC is $1.12 \mathrm{~g} / \mathrm{cc}$ and $30 \%$, respectively for Indian fly ash. Also, in Fig. 2b a similar type of observations has been reported by many researchers.

\subsection{Strength behavior of fly ash}

The strength characteristics of the fly ash can be estimated by knowing the angle of internal friction and cohesion value which can be determined using the triaxial shear test (Raymond 1961; Kumar and Mandal 2016) \& direct shear test (Muhunthan et al. 2004; Ratna and Darga 2015). Fly ash does not have plasticity characteristics, it is non-plastic in nature, therefore the cohesion of fly ash is less than that of soil (Pandian 2013). In the loosest state, fly ash develops 


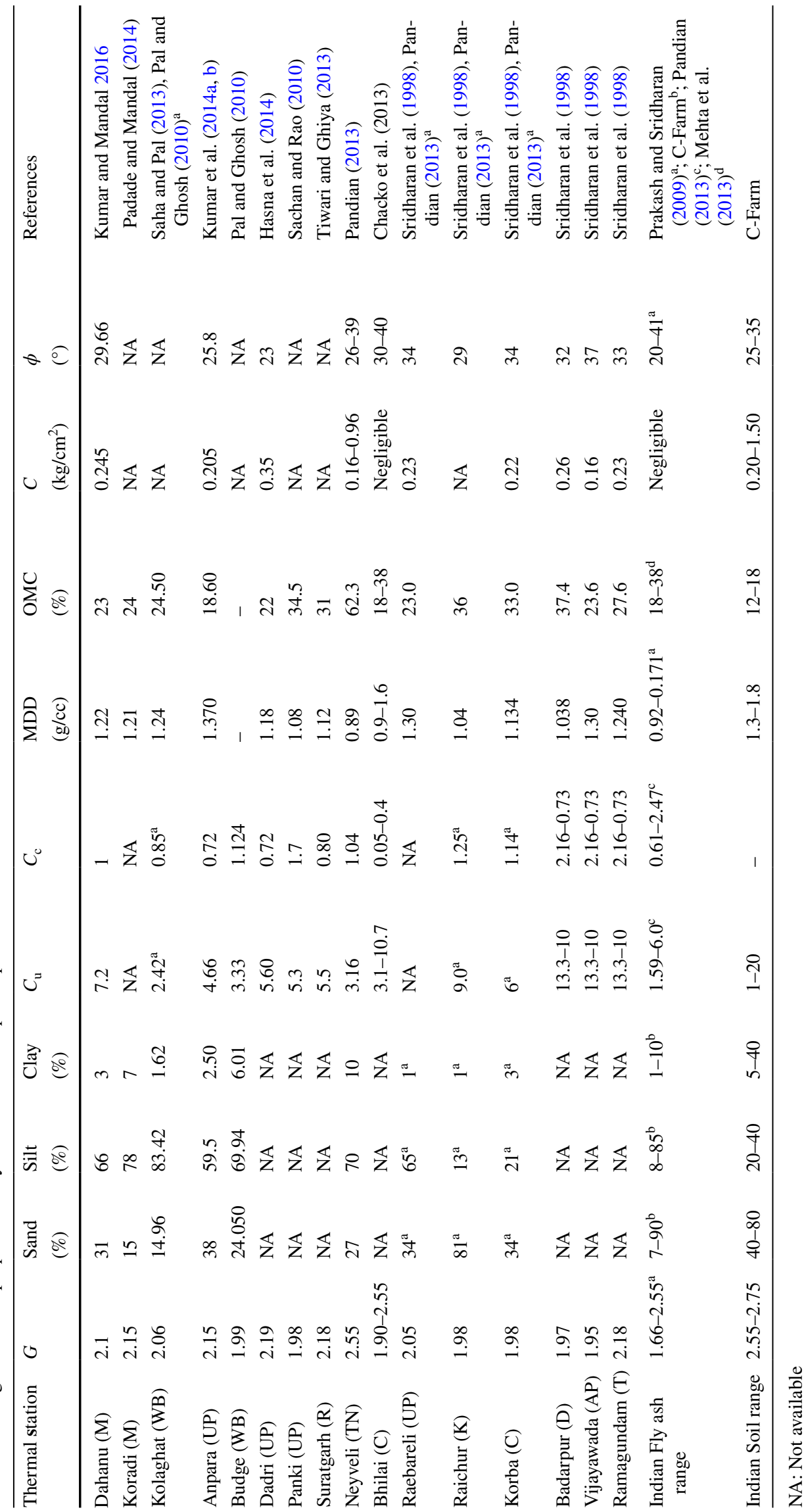


its shear strength mostly from friction between particles, whereas in compacted state, the development of shear strength accounts due to the frictional resistance (Sridharan et al. 1998). The range of frictional resistance of fly ash is from $30^{\circ}$ to $40^{\circ}$ that is comparable with soil $\left(25^{\circ}\right.$ to $\left.35^{\circ}\right)$ (C-Farm). The crushing strength of the granulated coal ash is independent of the size of the particle whereas it has a significant influence on the shear strength. It was reported that shear strength increases with an increase in the crushing strength of a single particle (Yoshimoto et al. 2012). It is also used for the strength improvement of local soil and it was observed that cohesion in the soil increases with the increase in fly ash content (Prabakar et al. 2004). The stabilization of soft soil was previously done using lime, which is now upgraded to fly ash. Lin et al. (2007) used sewage sludge ash for the improvement of soft cohesive soil subgrade. The findings of the study demonstrate that sludge ash is better to use in place of fly ash for the improvement in geotechnical properties.

The behavior of fly ash mixed with recycled plastic polymers has also shown enhancement in the shear strength properties (Salunkhe and Mandal 2014). The geotechnical characteristics of the local soil blend with fly ash and lime investigated by Viskochil et al. (1958) show its effectiveness for lime to fly ash ratio of 1:9-2:8. A similar kind of experiment has been done by Sahoo et al. (2010) and found that the addition of $15 \%$ fly ash \& $4 \%$ lime has increased the stabilized behavior of the soil. The maximum value of peak strength occurs when the slope of the plot between volumetric strain and axial strain is high (Kim et al. 2005). The low density fly ash shows more dilation as compared to the high density fly ash. The volumetric strain is significant in the case of high confining pressure. Since, it resists a load by friction only, therefore the peak friction angle $\left(\phi_{\mathrm{p}}^{\prime}\right)$ can be determined using the principal effective stress as a variable, expressed in Eq. (1).

$\sin \phi_{\mathrm{p}}^{\prime}=\left[\left(\frac{\sigma_{1}^{\prime}}{\sigma_{3}^{\prime}}\right)-1\right] /\left[\left(\frac{\sigma_{1}^{\prime}}{\sigma_{3}^{\prime}}\right)+1\right]$

where, $\sigma_{1}{ }^{\prime} / \sigma_{3}{ }^{\prime}=$ effective principal stress ratio or stress obliquity.

\subsection{Permeability behavior of fly ash}

Fly ash particles are generally found lesser than that of sand. Thus, the falling head permeability test is preferred for the determination of the permeability of fly ash. Permeability is a critical parameter in the following cases: settlement of foundations, the time required for consolidation, and for the dissipation of pore pressure (Shil and Pal 2015). It is dependent on many factors such as degree of densification, void ratio, grain size distribution, internal structure, soil type, etc. (Wang et al. 1984; Rajasekhar 1995). The permeability of fly ash resembles the permeability of non-plastic silts, on the other hand, compacted fly ash is defined as moderately permeable (Kaniraj and Gayathri 2004). The permeability of fly ash shows decreasing trend when used as a stabilizing agent in soil (Parker et al. 1977). The combination of fly ash and bentonite is very popular in the application of landfill liner. It is observed that a mixture of fly ash and bentonite in percentage of $95 \%+5 \%$ and $80 \%+20 \%$ shows superior results when used as a liner (Sankar and Niranjan 2015; Mollamahmutoğlu and Yilmaz 2001; Hasan et al. 2014). The permeability is highly interconnected with the effective size $\left(D_{50}\right)$ and size of the aggregate (Chen et al. 1977; Hauser 1978). The increment of both classes of fly ash leads to the decrement in permeability of concrete, with a certain amount of cement. Comparing Class $\mathrm{C}$ and Class F fly ash, the former one has not shown a satisfactory reduction in the permeability than that of the later one (Eliss et al. 1991). Meyers et al. (1976) specified that higher content of fines fills the interconnected voids in concrete. This results in lower permeability attributed to the high pozzolanic activity, which increases the amount of $\mathrm{SiO}_{2}, \mathrm{Al}_{2} \mathrm{O}_{3}$, and $\mathrm{CaO}$. The range of coefficient of permeability of Indian coal ash is shown in Table 3 and the variation of basic properties has been mentioned in Table 2. As shown in Table 3, the permeability of fly ash is low followed by pond ash and bottom ash. Pond ash is showing intermediate permeability because it is disposed of directly by blending fly ash and bottom ash. In field applications like road subgrade, it is applied and compacted in an alternate layer form, leading to the generation of an interface. This results in the variation of field permeability in comparison to the laboratory.

\section{Chemical characteristics of fly ash}

\subsection{Fineness of fly ash}

Fineness plays a remarkable role in the pozzolanic property of the fly ash. The increase in pozzolanic reactivity exhibits strong self-setting action of fly ash, which is due to the presence of fine content (Chatterjee 2011; FHWA-IF-03-019 2003; Wen and Xin 2003). The finer particles show a lesser percent of the residue left over 45 micron sieve (No. 325ASTM). Further, it was noticed that, if the residue is less than $10 \%$, then the strength increment is very significant (Sheng et al. 2007). The generation of leachate from the finer fly ash was found to be higher than that of coarser fly ash, because of the low pH of the finer fly ash (Kumar et al. 2016). Therefore, fine fly ash is more detrimental than that of coarse fly ash in terms of the production of harmful elements (Kumar et al. 2018). The finer particle (less than 63 microns) of fly ash can be utilized in cement and concrete 
Table 3 Range of coefficient of permeability of Indian coal ash (Pandian 2013)

\begin{tabular}{ll}
\hline Ash type & Coefficient range of permeability (cm/s) \\
\hline Fly ash & $8.00 \times 10^{-6}$ to $1.87 \times 10^{-4}$ \\
Bottom ash & $9.9 \times 10^{-5}$ to $7.0 \times 10^{-4}$ \\
Pond ash & $5.00 \times 10^{-5}$ to $9.62 \times 10^{-4}$ \\
\hline
\end{tabular}

industries because of its high self-cementing properties. Fly ash reduces the cement fraction in concrete, which results in cost reduction of concrete (Vassilev and Vassilev 2007). The enhancement in the strength of the mortar due to higher fine content in fly ash was approved by many researchers (Antiohos and Tsimas 2005; Tsimas and Moutsatsou 2005; Erdoğdu and Türker 1998). Higher fine content results in a reaction of $\mathrm{CaO} \& \mathrm{CaSO}_{4}$ with water and dissolution of active $\mathrm{SiO}_{2}$ and $\mathrm{Al}_{2} \mathrm{O}_{3}$ attributed to the early formation of ettringite, hydrated calcium silicate, and gypsum, which helps in the early development of strength (Sheng et al. 2007).

\subsection{Color}

Color has a significant impact on the broad classification of the class of fly ash. The color of the fly ash is primarily based on the origin and mineralogical composition of the coal, which is explained in Table 4. Indian fly ash usually shows light to dark gray color, and mostly varies from tan to gray to buff (Fan et al. 2005). The color of the fly ash is influenced by the presence of unburned carbon and iron (Ahmaruzzaman 2010). Higher lime content is typically associated with light to tan color, whereas the presence of iron content results in brownish color of the fly ash. Similarly, a higher amount of unburned carbon resulted in dark gray to black color (FHWA-IF-03-019 2003). The class C fly ash (combustion of lignite or sub-bituminous) generally shows a light tan to buff in color because of the presence of calcium (lime). It is reported that the presence of unburned carbon is responsible for the dark gray color of class F fly ash (Recycled Material Resource Center). Light color fly ash represents good quality ash as compared to black or dark color fly ash (EPA (2005)). The color gives a broad idea about the quality and composition of the fly ash \& acts as a primary source of classification (Roy and Griffin 1982).

\subsection{Loss on Ignition (LOI)}

Loss on Ignition is directly associated with the quality/ application of the fly ash in terms of unburned carbon and metallic oxides. Fly ash has a high value of the LOI, which adversely affects the quality of the fly ash. Owing to the adverse quality of the fly ash, its application in cement/concrete industries is restricted (Blissett and Rowsan 2012). EN
Table 4 Color variation of fly ash based on mineralogical content (Vassilev and Vassileva 2007)

\begin{tabular}{ll}
\hline Color of fly ash & Mineralogical content \\
\hline Reddish or Brown & Hematite, Fe-hydroxides, Ferrispheres \\
Dark and Light gray & Char, Magnetite, Ferrispheres \\
White or Cream & Quartz, Mullite, Lime, Portlandite, \\
& Calcite, Anhydrite, Alumino-silicate \\
& glass \\
\hline
\end{tabular}

450 (1995) limits the LOI less than equal to $5 \%$, whereas the revision of European code EN450 (2005) classified fly ash based on the LOI as A (less than 5\%), B (2.0\%-7.0\%), and $\mathrm{C}(4.0 \%-9.0 \%)$. The LOI is measured by burning the fly ash sample at a temperature of about $1000{ }^{\circ} \mathrm{C}$ or 1050 ${ }^{\circ} \mathrm{C}$ (Vassilev and Vassilev 2007; Odler and Zysk 1989). The higher efficiency of CFBC (Circulating Fluidized Bed Combustion) technology leads to the generation of low LOI fly ash as compared to the conventional FBC (Fluidized Bed Combustion) technology (Rajaram 1999). Concrete with fly ash having $8 \%$ LOI shows a marginal change in compressive strength and durability behavior (McCarthy and Dhir 1999). There are many applications of fly ash that are not influenced by the LOI, such as filler in asphalt, flowable fill, and structural fills (FHWA-IF-03-019 2003). According to the IS 3812 (P-2-2013) and ASTM C618-17a, the permissible limits of LOI for fly ash are $7 \%$ and $6 \%$ respectively.

\subsection{Physical shape of fly ash}

The shape of the fly ash predominantly consists of a spherical particle having a glassy (transparent) nature with a wide range of particle size (clay to fine sand) (Dudas and Warren 1987; Awang et al. 2012; Eze et al. 2013). The combustion temperature and cooling rate are the two main factors responsible for the morphology \& composition of the fly ash (Kutchko and Kim 2006). Rapid cooling of the fly ash leads to the generation of spherical (non-crystalline) particles. The combustion temperature inside the chamber has a significant influence on the shape of the particle (McCrone and Delly 1973). The amorphous particles with little rounded and rounded edge resulted from the exposure conditions of low \& high temperature (Fisher et al. 1978). The spherical shape of the fly ash attributes to the "ball bearing mechanism" explained by Kamruzzaman et al. (2003). Due to this 
mechanism, it exhibits some advantageous features such as increased workability, high permeability, and reduced friction between particles (FHWA-IF-03-019 2003). The shape characteristics of the fly ash have been classified into 11 different classes using Scanning Electron Microscope and Light Microscopy by Small (1976) and Fisher et al. (1978). Sarkar et al. (2012) investigated the fly ash collected from different fields and found that fly ash collected from starting field is irregular and large in shape, whereas fly ash collected from far field shows a much regular spherical shape.

\subsubsection{Cenospheres/plerospheres}

Spherical hollow fly ash particle having thin walled \& smooth surface is termed as cenospheres, whereas plerospheres are spheres that consist of a small size sphere inside it (Paulson and Ramsen 1970; Page et al. 1979; Dudas and Warren 1987). Both of these spheres are very common in low calcium fly ash than that of high calcium fly ash (Das and Yudhbir 2005). The concentrations of cenospheres/plerospheres are reliant on the carbon and iron content (Kolay and Singh 2001). The fundamental time required for the development of 50 micron plerospheres and cenospheres is $1 \mathrm{~ms}$ (Fisher and Natusch 1979) \& 0.3 ms (Raask 1968) respectively. About $1 \%-2 \%$ of cenospheres are generally present in fly ash and it is very light in weight (Wolfe and Gjinolli 1999; Siddique 2010). Cenospheres consist of alumina-silica, iron, and alkali at its outmost shell (Sarkar et al. 2007) and their size vary from 1 to $300 \mu \mathrm{m}$ (Torey 1978). The segregation of cenospheres from the fly ash can be done by the wet separation technique (Manocha et al. 2011) and the dry separation technique (Hirajima et al. 2010). The cenospheres have beneficial properties like low density, chemically inert, light weight, and excellent thermal resistance (Raask 1968; Fisher et al. 1976; Bhatt et al. 2019), which enhances the application of fly ash in light weight filler and aggregate (Hanif et al. 2017).

\subsection{Specific Surface area of fly ash}

The Blaine air permeability test is widely accepted to evaluate the specific surface area (SSA) of the fly ash (JIS 1997; Grzeszczyk and Lipowski 1997). The Blaine's test is easy to conduct, but it underestimates the SSA due to the assumption that the particles are spherical in shape and the same size as that of the laser diffraction test, whereas the nitrogen absorption test overestimates the SSA of fly ash (Wang et al. 2018). The consistency of SSA of fly ash has been observed only in the method of image analysis coupled with backscattered electrons. However, it required more time for the sample preparation. The SSA has a noticeable effect on the pozzolanic property, development of strength, physiochemical properties, and sustainability of the fly ash blend concrete (Erdoğdu and
Türker 1998; Grzeszczyk and Lipowski 1997; Chindaprasirt et al. 2004, 2005). The sample collected from the far end of the hopper of the electrostatic precipitator shows higher values of SSA (Hemming and Berry 1987; Lee et al. 1999), which means the finer the fly ash more will be it's SSA (Misra 1998). The compressive strength and pozzolanic reactivity of the fly ash depict improvement when residue left over 45 micron sieve is lower (Diaz et al. 2010; Nurwidayati et al. 2016). The shape and size are the governing parameters having a dominant influence on the magnitude of SSA. In general, the shape of the fly ash is considered as spherical for the ease of calculation (Schure et al. 1985; Shirai et al. 2011). The minimum physical requirement of SSA of fly ash is $200 \mathrm{~m}^{2} / \mathrm{kg}$ (IS 3812-P2-2013).

\subsection{Strength Activity Index (SAI)}

The strength activity index is represented as a ratio of the strength of compressive strength test and standard sample evaluated by ASTM C 311-07 (2007). The mechanical grinding of the fly ash enriched its performance in hydration of fly ash based cement (Paya et al. 1995; Li and Wu 2005). Bouzoubaa et al. (1997) used the ball of 20 and $30 \mathrm{~mm}$ diameter in grinding mill for different time intervals and encountered that $4 \mathrm{~h}$ grinding gives optimum SAI. The strength activity index of concrete represents a valuable increment when $25 \%$ of CFBC fly ash is replaced by cement than that of $75 \%$ of fly ash (Wu et al. 2014). Jaturapitakkul et al. (1999) and Kiattikomol et al. (2001) have grinded coarse grain fly ash into fine grain (approx. 1.9 microns) and observed that the development of $110 \%$ and $121 \%$ SAI at the early stage and at 90 days respectively. A similar type of improvement in the strength of early stage has been observed using ultra fine fly ash, which ultimately enhanced the SAI (Supit et al. 2014). Moreover, some researchers considered fine glass powder \& rice husk ash and found a similar trend of increment of SAI (Schwarz and Neithalath 2008; Rukzon et al. 2009). When 20\% (by weight) of cement is replaced by fly ash then fly ash mortar should have at least $75 \%$ of SAI as compared to standard mortar at the age of 7 and 29 days (ASTM C618).

\section{7 $\mathrm{pH}$ of fly ash}

The $\mathrm{pH}$ value of the fly ash is generally more than the other classes of coal ash and depicts the alkaline behavior (FAM 2001). The classification of fly ash based on $\mathrm{pH}$ is explained in Table 5. Fly ash produced in India falls in the $\mathrm{pH}$ range of acidic ash. The more elevated magnitude of $\mathrm{pH}$ of class $\mathrm{C}$ fly ash and fly ash with alkaline oxides has been observed by Pandian (2013). The $\mathrm{pH}$ of natural soil varied in the range of 5-8, which has increased to 12.8 when it got mixed with lime and fly ash (Dermatas and Meng 2003). Similarly, the application of fly ash (8\%) to the calcareous soil and acidic soil results in an increment of pH from 8 to 10.8 and 5.4 to 9.9 (Page et al. 
1979) respectively. This increase in $\mathrm{pH}$ of the soil is due to the accelerated production of $\mathrm{Ca}, \mathrm{Na}, \mathrm{Al}$ and $\mathrm{OH}$ ions in the fly ash (Wong and Wong 1990). Plank and Martens (1974) and Page et al. (1977) have found fly ash characteristics from acidic to basic range ( $\mathrm{pH} 4.5$ to 12 ). The prominent content of sulfur leads to the generation of low $\mathrm{pH}$ ashes. In addition, leachate produced from the fine fly ash is composed of high trace elements because of the low $\mathrm{pH}$ in comparison with coarser particles (Tan and Xiao 2012). The use of a significant amount of fly ash introduces changes in the $\mathrm{pH}$ of the soil and increases the salinity of the soil (Sharma et al. 1997).

\subsection{Pozzolanic behavior of fly ash}

The pozzolanic materials are divided into natural (pyroclastic rock, tuffs, metakaolin, and calcined clay) and artificial (fly ash, silica fume, burned clay, and shale) pozzolanas. The volcanic ashes produced from the explosive eruption possess better pozzolanic properties, whereas non-explosive eruption shows less pozzolanic reactivity due to the gradual cooling process. These materials are alumino-siliceous materials that react with $\mathrm{Ca}(\mathrm{OH})_{2}$ when comes in contact with water in grounded forms and lead to the generation of a cementitious compound. The development of this reaction can be investigated by two parameters (i) reduction in $\mathrm{f}-\mathrm{CaO}$, and (ii) increment in solubility of silica $\&$ alumina in acid. Moghal (2017) classified the fly ash into (i) self-pozzolanic, (ii) pozzolanic, and (iii) non-pozzolanic type. Pozzolanic property of class F (highest rank fuel) fly ash is high as compared to that of class $\mathrm{C}$ (lowest rank fuel) fly ash. The pozzolanic behavior of modified CFBC fly ash is higher than that of CFBC \& PFA ( $\mathrm{Li}$ et al. 2012). The pozzolanic reactivity of coal ash reduces significantly when the coal has burned with biomass. In FBC technology, the desulphurization of the fly ash results in high calcium oxide and sulphur trioxide. However, it reduces the pozzolanic activity. It increases with an increase in the fineness of the fly ash. Generally, it is not recommended to use pozzolanic material below $4.4{ }^{\circ} \mathrm{C}$ because of the slow development of the strength. The chemical properties of the fly ash, which changes its pozzolanic properties has been tabulated in Table 6. From Table 6, it can be concluded that the predominance of $\mathrm{SiO}_{2}, \mathrm{Al}_{2} \mathrm{O}_{3}$, and $\mathrm{Fe}_{2} \mathrm{O}_{3}$ are high in the fly ash irrespective of the location of the production in India.

\subsection{Leaching nature of fly ash}

The leaching of heavy metals or toxic major elements from the fly ash is not favourable from an environmental point of view. The same was verified by both natural and artificial techniques. The leaching process is much appreciable when highly concentrated acid is used (Andrade et al. 1989). The standard of limestone, $\mathrm{pH}$, leaching medium, solid/liquid
Table 5 Classification of fly ash on the basis of its $\mathrm{pH}$ range (Kolbe et al. 2011)

\begin{tabular}{ll}
\hline Fly ash & $\mathrm{pH}$ value \\
\hline Acidic ash & $1.2-7$ \\
Mildly Alkaline ash & $8-9$ \\
Strong Alkaline ash & $11-23$ \\
\hline
\end{tabular}

ratio, leaching time, and temperature of the water are the parameters, which greatly influence the fly ash response (Baba et al. 2010; Nayak and Panda 2010). The electrical conductivity of leachate produced from the bituminous coal is higher than that of anthracite coal. The elements that leach out from the fly ash are in a great extent attributed to the surface of the ash particles (Choi et al. 2002). The leaching test is generally performed by the batch test because of its simple and quick nature (Jones 1995; Ugurlu 2004). After leaching, the trace elements encountered by a number of researchers are $\mathrm{Fe}, \mathrm{Mn}, \mathrm{Ca}, \mathrm{As}, \mathrm{Pb}, \mathrm{Mg}, \mathrm{Cr}, \mathrm{Co}, \mathrm{Cu}, \mathrm{Cd}, \mathrm{Ni}, \mathrm{Zn}$ (Andrade et al. 1989; Khanra et al. 1998; Shim et al. 2005; Oliveira et al. 2012; Singh et al. 2012). Also, an element like $\mathrm{Ca}, \mathrm{Na}, \mathrm{K}, \mathrm{Mn}, \mathrm{Fe}, \mathrm{S}, \mathrm{Pb}$ shows higher leaching potential, whereas $\mathrm{Cd}, \mathrm{Mg}, \mathrm{Cu}, \mathrm{Cr}, \mathrm{Zn}$, Co has the minimum potential (Ugurlu 2004). Singh et al. (2016) found little contradictory results, which show $\mathrm{Mn}, \mathrm{Mg}, \mathrm{Cr}, \mathrm{Zn}, \mathrm{Ni}, \mathrm{Pb}, \mathrm{Fe}$ in higher concentration and $\mathrm{Hg}$, Mo, Co in a lower concentration.

\section{Consequences of unburned carbon in the applicability of fly ash}

The unburned carbon is the result of the inadequate burning of the coal. The LOI is the most common method used for its determination, but for better precision thermogravimetric analysis can be done because LOI overestimates the overall result. It is usually available in particle range of $30-50$ microns (Xiao et al. 2005) that leading to the higher coarser content in the fly ash. The carbon generated from the low quality coal combustion process results in the efficient removal of $\mathrm{Hg}$ in comparison to carbon from the high quality coal (Hower et al. 2010). Also, the carbon percentage reduces as the distance of precipitator increases from the near end to the far end (Lee et al. 1999). Maier et al. (1994) has found that the pulverized coal having a fraction greater than 150 microns produces low unburned carbon; however, it reduces $\mathrm{NO}_{x}$ removal efficiency. The most significant property responsible for adsorbing the nature of carbon in fly ash is a porous structure (Wang et al. 2005). It plays a key role in the recommendation of the appropriateness of the fly ash as a cementitious constituent for concrete. The presence of unburned carbon is unfavorable in the potential application of fly ash because it arrests the function of air entraining admixture in concrete. The hydrophobic part of the admixture is combined with the available carbon and resulted in the inadequacy for their primary function. On the 


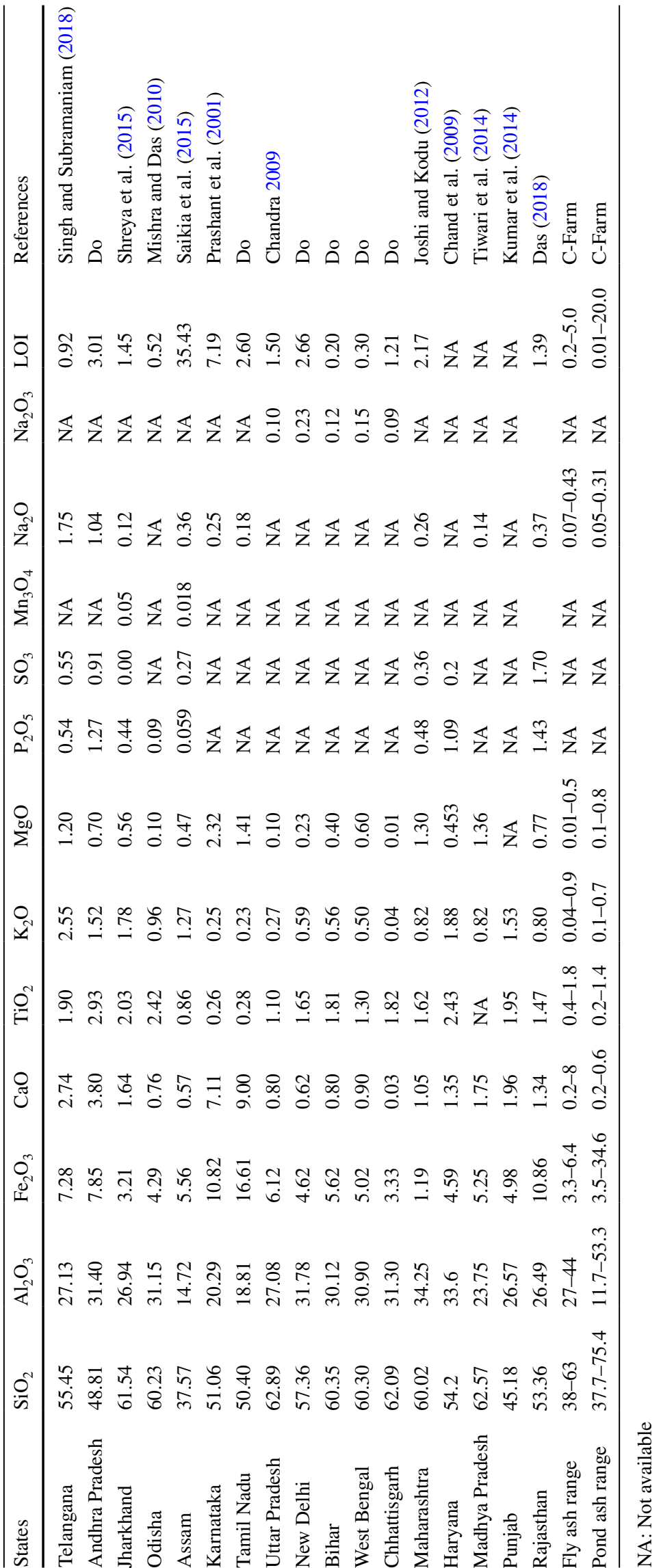


other hand, segregation of the mix and discoloration is another difficulty associated with the unburned carbon in concrete. The term referred as foam index is used to represent the interrelation between admixture and carbon. Freeman et al. (1997) signify that a high value of air entraining is required for a high magnitude of foam index. In addition, it is advantageous in predicting the efficiency of a boiler as well as aiding in the removal of mercury (Hower et al. 2017).

\section{Particle shape/structure of fly ash}

The majority of fly ash follows the trend having an irregular shape particle in a large size range and a smooth shape particle in a small size range. The unburned carbons are more prominent in irregular shapes and show high potential of sorption. Zhu et al. (2013) segregated the fraction of the fly ash particles into six groups $(<20,20-45,45-75,75-106,106-150,>150$ microns). They concluded that the highest proportion of ash particles is coming under 20 microns with a smooth surface texture. The properties of the coal ash or other pozzolanic material are usually determined by the standard methods available for finding the properties of cement. There is no standard method for the determination of coal ash properties, so whatever assumptions were taken in cement standards are referred for the coal ash. This not only provides an indefinite trend but also results in misleading the actual data. The methods for the grain size distribution are laser diffraction (LD), image analysis (IM), and mercury intrusion porosimetry (MIP). Among the above mentioned methods, MIP provides reliable and accurate results (Arvaniti et al. 2015). Similarly, the methods available for the determination of the specific surface area (SSA) are Blaine air permeability, nitrogen absorption test (NAT), LD, and IM. Blaine air permeability and LD method assumed spherical shape of the fly ash particle due to which it underestimates the SSA. However, NAT overestimates the SSA due to the presence of unburned carbon (Wang et al. 2018). The application of fly ash depends on the method of characterization, such as in superplasticizer consumption, the total surface area required can be calculated by Brunauer-Emmett-Teller (BET). On the other hand, the determination of reaction rate involves only the surface area of the reactive part rather than the total surface area. The surface area of the reactive part can be calculated by LD, IM, and MID. The relationship between SSA and other factors using the method BET, LD, and IM has been listed below in the form of Eqs. (2)-(5).

$$
\begin{aligned}
& \mathrm{SSA}_{\mathrm{BET}}=\frac{N_{\mathrm{A}} V_{\mathrm{m}} A_{\mathrm{N}}}{V_{\mathrm{o}}} \\
& \mathrm{SSA}_{\mathrm{LD}}=\frac{F \times 1 \times 10^{4}}{\rho} \sum \frac{6 f_{\mathrm{LD}}}{d}
\end{aligned}
$$

$\mathrm{SSA}_{\text {img }}=\frac{4}{\pi \rho} B_{\mathrm{A}}$

$$
B_{\mathrm{A}}=\frac{N_{\mathrm{P}}}{N_{\mathrm{A}} L_{\mathrm{S}}}
$$

The SSA of single particle considering the spherical shape can be estimated geometrically using Eq. ( 6 )and the combined SSA as a whole can be estimated by using Eq. (7) (Schure et al. 1985).

$S_{\mathrm{G}}=\frac{A}{m}=\frac{\pi d^{2}}{(\rho / 6) \pi d^{3}}=\frac{6}{\rho d}$

$S_{\mathrm{G}}=\frac{\sum_{i=1}^{n} A_{i}}{\sum_{i=1}^{n} m_{i}}=\frac{6 \sum_{i=1}^{n} d_{i}^{2}}{\rho \sum_{i=1}^{n} d_{i}^{3}}$

where $N_{\mathrm{A}}$ is Avagadro constant, $V_{\mathrm{m}}$ is amount of gas needed to cover the surface with a monolayer, $V_{\mathrm{o}}$ is molar volume of gas, $A_{\mathrm{N}}$ is surface area of single adsorb molecule, $\mathrm{F}$ is empirical correction factor (1.13), $f_{\mathrm{LD}}$ is Grain's volume fraction, $\mathrm{d}$ is diameter of grains, $\rho$ is average density, $B_{\mathrm{A}}$ is density of boundary length of section area, $N_{\mathrm{P}}$ is quantity of external boundaries \& internal edges of fly ash, $N_{\mathrm{A}}$ is quantity of pixels of fly ash, $L_{\mathrm{S}}$ is edge length of each pixel, $A$ is particle surface area and $m$ is mass.

\section{Fly ash dosage in the various area of engineering}

The dosage of fly ash is a very important aspect for the utilization of fly ash because it varies for different applications. Fly ash alone cannot achieve the desired strength when used in concrete. Therefore, fly ash is generally added as a partial replacement of cementitious material. Consoli et al. (2011, 2016) studied the combination of soil, fly ash, and lime based on an unconfined compression test and proposed some equations, which is valid for fly ash range $0 \%-25 \%$, lime range $3 \%-9 \%$, and dry unit weight range $14-17 \mathrm{kN} /$ $\mathrm{m}^{3}$. The equation relating to dosage of the above material with strength is mentioned below:

$\eta=100\left[1-\frac{\gamma_{\mathrm{d}}}{1+\left(\frac{L}{100}\right)}\left(\frac{100-F A}{100 \gamma_{\mathrm{s}}}+\frac{F A}{100 \gamma_{F A}}+\frac{L}{100 \gamma_{L}}\right)\right]$

$L_{i v}=100\left(\frac{\gamma_{\mathrm{d}}}{1+\frac{L}{100}}\right)\left(\frac{L}{100 \gamma_{L}}\right)$ 
$q_{\mathrm{u}}=5.89 \times 10^{8} F A\left[\frac{\eta}{\left(L_{i v}\right)^{0.12}}\right]^{-4.6}$

where, $\eta$ is porosity, $L_{\mathrm{iv}}$ is volumetric binder content, $q_{\mathrm{u}}$ is unconfined compressive strength, $F A$ is fly ash (\%), $L$ is lime content $(\%), \Upsilon_{\mathrm{d}}$ is dry unit weight.

Kumar et al. (2005) investigated yields of agricultural fields using fly ash from 50 different locations and found that the yield increases from 10 to $40 \%$ with the addition of 10 to 200 tonnes/ha of fly ash. The dose of fly ash required for rice in alluvial soil and black soil is higher than that of lateritic soil. The fly ash increases the physical and hydrological properties of the soil when its proportion is less than $2 \%$ by weight (Yunusa et al. 2011). Similarly, the replacement of binding material for concrete is generally kept $25 \%-30 \%$ by the weight of cementing materials as shown in Table 7. According to the dose level of fly ash in concrete, it is divided into low $(<15 \%)$, medium $(15 \%-30 \%)$, high $(30 \%-50 \%)$, and very high (>50\%) (Thomas 2007). A higher dose level $(30 \%-50 \%)$ can also be used to control the rise in temperature in huge structures like dams and foundations. Marceau (2002) reveals that the dose level $40 \%-0 \%$ can be used in structural constructions with sufficient durability and superior mechanical properties. It is used in the manufacturing of paver blocks, cement bricks, and clay bricks. The compressive strength of the fly ash-clay fired brick was observed to be $98.5 \mathrm{MPa}$ (Lingling et al. 2005). For successful utilization of fly ash as construction material, it is essential to maintain the range/proportion discussed in Table 7. This is because it depends upon many factors such as type of application, required properties, durability, type of mixing material, location of application, type of fly ash, etc. It has to be noted that higher dose of fly ash is undesirable for construction works as it reduces the required strength. From Table 7, it can be seen that for higher amount of utilization of fly ash, the application must be focused on areas such as fired bricks, asphalt pavement, light weight aggregate, and sound absorbing materials.

\section{Fly ash recognition as Green/ non-hazardous or hazardous}

A material is classified as hazardous when it shows the following nature: flammable, corrosive, toxic, reactive, and harmful to human health. Fly ash has most of the properties mentioned above, but it is classified as non-hazardous material. Table 8 represents toxic chemical and their harmful effects to human body parts, out of these toxic chemicals majorities of the chemicals are generally found in coal ash. The presence of arsenic, antimony, boron, lead, and cadmium affects the more number of body parts. Earlier, it was present under the group of hazardous industrial waste, eventually, after the year 2000, it was reclassified as waste material/non-hazardous material (Issues in utilization of ash by thermal power plants (2015)). As per National Hazardous Waste rules, if the ash residues are supposed to have remarkable hazardous materials, then it is important to test at the start of plant operations for classification (EIA Guidance manual 2010). Seventy six coal ash pond failures have been seen in the last decade (2010-2020). One of the health study conducted in Chhattisgarh (India) reveals that the people living near the ash ponds are facing health issues like hair fall, head and body ache, kidney and gastrointestinal problems, etc. (The Health and Environmental Impact of coal mining in Chhattisgarh (2017)). Similar types of health studies have been conducted by the United States Environmental Protection Agency and found 1 in 50 chance of getting cancer from the water consumed, which was contaminated by arsenic (U.S. Environmental Protection Agency (2007)).

In comparison with other naturally available building materials, fly ash shows high radioactivity, but it remains under the permissible limits (Haquin 2008). Sjöblom (2014) discussed a feasible method to identify the hazardness/nonhazardness of the fly ash in a realistic manner. He selected a reference substance followed by finding the hazardous property of selected substances with risk phrase. Thereafter, the sum value for each concentration was found out, which was compared with the limits.

If the sum value is greater than the limits, then it is classified as hazardous and vice-versa. Leaching results also play a significant role in the selection of reference substances. From the above discussion, it is clear that the fly ash is a hazardous material if not managed/disposed properly. It contaminates surface water, sub-surface water, soil, air quality that resulting in various health related problems. Therefore, it is essential to identify the place that should be free from human habitations, sources of water, prone to earthquake, etc. for the safe disposal of coal/fly ash.

\section{Application of fly ash}

Fly ash is predominantly used as supplementary cementitious material, with cement, lime, or other binding material. For the construction of an embankment, or structural fill, low calcium fly ash is used frequently as compared to high calcium lime. The higher performance of fly ash can be achieved by considering the dosage of class $\mathrm{F}$ and class $\mathrm{C}$ fly ash from $15 \%-25 \%$ and $15 \%-40 \%$, respectively (Rodriguez 2019). The higher concentration of unburned carbon (high LOI) resulted in limited application such as flowable/ structural fill and filler in asphalt. Fly ash used as filler in asphalt mix improves its stiffness, which in turn decreases the ruts formation in the pavement (EPA (2005)). According 
Table 7 Demonstration of dosage/proportion of fly ash in different areas of application

\begin{tabular}{|c|c|c|c|c|}
\hline Scope & Constituents & Proportion & Remarks & References \\
\hline \multirow[t]{9}{*}{ Construction material } & Cement mortar-Fine FA & $40^{*}$ & Very fine FA gives higher strength & Chindaprasirt et al. (2004) \\
\hline & Fired Bricks_FA: Clay & 50: 50 & $\begin{array}{l}\text { PI of mixture reduces with an } \\
\text { increment of FA }\end{array}$ & Lingling et al. (2005) \\
\hline & Self compacting concrete-FA & $40^{*}$ & $\begin{array}{l}\text { High replacement of FA leads to } \\
\text { reduction in strength }\end{array}$ & Liu (2010) \\
\hline & $\begin{array}{l}\text { Polymer concrete-Epoxy resin: } \\
\text { FA \& Silica: Aggregate }\end{array}$ & 13.2: $7.2: 79.6$ & $\begin{array}{l}\text { FA and Silica helps in high devel- } \\
\text { opment of strength }\end{array}$ & Barbuta et al. (2010) \\
\hline & $\begin{array}{l}\text { Self compacting concrete (SCC) - } \\
\text { FA }\end{array}$ & $25^{*}$ & $\begin{array}{l}\text { Abrasion resistance decreases with } \\
\text { an increase in FA beyond 25\% }\end{array}$ & Turk and Karatas (2011) \\
\hline & Self compacting concrete-FA & $30^{*}$ & $\begin{array}{l}30 \% \text { of FA replacing cement } \\
\text { results in concrete of } 100 \mathrm{MPa} \\
\text { strength }\end{array}$ & Dinakar (2013) \\
\hline & $\begin{array}{l}\text { Reclaimed Asphalt Pavement } \\
\text { (RAP)—FA: Aggregates and } \\
\text { RAP }\end{array}$ & 40: $60(80: 20)$ & $\begin{array}{l}\text { This proportion met the IRC } \\
\text { guidelines for base/subbase } \\
\text { material }\end{array}$ & Saride et al. (2015) \\
\hline & $\begin{array}{l}\text { Nanosilica: FA: Cement: Aggre- } \\
\text { gates }\end{array}$ & $6: 30: 15: 49$ & $\begin{array}{l}\text { Adding Nanosilica and FA } \\
\text { enhanced its binding in the } \\
\text { matrix }\end{array}$ & Ghazy et al. (2016) \\
\hline & $\begin{array}{l}\text { Cement stabilized macadam } \\
\text { (CSM)_FA }\end{array}$ & $25^{*}$ & $\begin{array}{l}\text { Increasing curing time will } \\
\text { enhanced mechanical properties } \\
\text { of CSM }\end{array}$ & Yan et al. (2019) \\
\hline \multirow[t]{2}{*}{ By-products } & $\begin{array}{l}\text { Artificial light weight aggregate- } \\
\text { FA: Fine quartz sand: Lime and } \\
\text { Additives }\end{array}$ & 50: $45: 5$ & $\begin{array}{l}\text { Sintering process adopt FA with } \\
\text { high carbon content }\end{array}$ & Bijen (1986) \\
\hline & $\begin{array}{l}\text { Sound absorbing material-FA: } \\
\text { Coal powder: } \mathrm{H}_{2} \mathrm{O}_{2}: \text { Slag }\end{array}$ & 50: 30: 1.0: 19 & $\begin{array}{l}\text { Material shows high sound } \\
\text { absorption and good mechanical } \\
\text { properties }\end{array}$ & Sun and Guo (2015) \\
\hline \multirow[t]{5}{*}{ Soil stabilization } & FA: Lime: Clayey soil & 20: $8.5: 71.5$ & $\begin{array}{l}\text { CBR value increases } 5.7 \% \text { by add- } \\
\text { ing FA and Lime }\end{array}$ & Sharma et al. (2012) \\
\hline & Lime: FA: Soil & $9: 25: 66$ & Lime and FA increases its MDD & Consoli et al. (2016) \\
\hline & BA: Soil & 30: 70 & $\begin{array}{l}\text { BA can be used as both improve- } \\
\text { ment and replacement }\end{array}$ & Gullu (2014) \\
\hline & FA: Lime: $\mathrm{Cr}^{6+}$ contaminated soil & 25: $10: 65$ & $\begin{array}{l}\text { Significant reduction in leachabil- } \\
\text { ity has been achieve }\end{array}$ & Kostarelos et al. (2006) \\
\hline & Brick—FA: Clay & 20: 80 & $\begin{array}{l}\text { Lower efflorescence has observed } \\
\text { in FA added bricks }\end{array}$ & Abbas (2017) \\
\hline \multirow[t]{4}{*}{ Agricultural field } & Alluvial soil & $0-200 \mathrm{t} / \mathrm{ha}$ & Rice, Wheat & Kumar et al. (2005) \\
\hline & Laterite soil & $0-10 \mathrm{t} / \mathrm{ha}$ & Rice, Groundnut & \\
\hline & Black soil & $0-80 \mathrm{t} / \mathrm{ha}$ & Sunflower, Maize & \\
\hline & Red soil & $30-60 \mathrm{t} / \mathrm{ha} / 3 \mathrm{yrs}$ & Sunflower, Groundnut & \\
\hline \multirow[t]{2}{*}{ Elimination of elements } & Removal of phosphorus & 4-20 g per lit & $\begin{array}{l}\text { Removal efficiency }>99 \% \text { and } \\
\text { higher at } 40{ }^{\circ} \mathrm{C}\end{array}$ & Ugurlu and Salman (1998) \\
\hline & Removal of Phenol & $1.0 \mathrm{~g}$ per $50 \mathrm{~mL}$ & $\begin{array}{l}\text { Mechanism of adsorption is gov- } \\
\text { erned by the surface characteris- } \\
\text { tics of FA }\end{array}$ & Sarkar et al. (2006) \\
\hline
\end{tabular}

FA: Fly Ash, IRC: Indian Road Congress, CBR: California Bearing Ratio, MDD: Maximum Dry Density, ${ }^{*}$ Cementitious material replaced by Fly ash

to ASTM E1861 (1997), it is very significant to provide a drainage layer in the application of structural fill. However, it should be assured that the water table is at least 5 feet below the drainage layer. If a vibratory roller is used, the first pass should be made by the roller in the static mode (without any vibration), followed by two passes with the roller in the vibratory mode at a relatively faster rate. Additional passes should be in the vibratory mode at a slower speed (ASTM E1861 (1997)). It is not possible to use coal ash alone for the construction of railway embankment due to its heavy load movements. The stabilization of the soil subgrade has been done by proper mixing of fly ash with lime/soil using 
Table 8 Impact of toxic elements in all parts of the human body (Coal ash in India - A compendium of Disasters, Environmental and Health Risks (2020))

\begin{tabular}{lll}
\hline Sample No. & All parts of body & Toxic elements \\
\hline 1 & Nervous system & Arsenic, lead, boron, manganese, mercury, selenium, thallium, vanadium \\
2 & Brain & Aluminium, boron, lead, manganese, mercury, PM2.5 \\
3 & Eyes & Antimony, Arsenic, Boron, Cadmium, Chromium \\
4 & Nose & Antimony, Arsenic, Boron, Cadmium, Manganese \\
5 & Throat & Antimony, PM2.5, Thallium \\
6 & Lungs and respiratory system & Aluminium, Boron, Lead, Manganese, Mercury, PM2.5 \\
7 & Heart & Antimony, PM2.5, Thallium \\
8 & Liver & Antimony, Arsenic, Boron, Cadmium, Chromium, Manganese, Thallium \\
9 & Kidney & Antimony, Boron, Cadmium, Chromium, Lead, Mercury, Silica \\
10 & Intestine & Boron, Lead, Mercury \\
11 & Muscle and Joints & Lead, Manganese, Molybdenum \\
12 & Skin & Antimony, Arsenic, Cadmium, Chromium, Selenium, Zinc \\
\hline
\end{tabular}

a rotavator or other mechanical mixers (Report on Fly ash utilization in road construction (2015)). The uniform thickness of $300 \mathrm{~mm}$ was considered for the compaction of the fly ash layer. The pond ash used in the construction of an embankment and subgrade in the national highway project (from Dankuni to Kolaghat) was compacted with sand \& soil in the proportion of $85: 15$ (pond ash:sand) and 75:25 (pond ash: soil) (GE:0-S005 (2006)) respectively. Similarly, some codal provisions are mentioned in Table 9 , which is very much useful in the perfect utilization of fly ash. The aim of these standards is to minimize the difficulties involved in the application of fly ash with the help of recommendations. The detailed application of fly ash in different fields of engineering has been shown in Fig. 3. Initially, the utilization of fly ash starts from structural engineering, which is gradually shifted towards chemical and other engineering applications. However, fly ash should be applied in geotechnical or transportation sectors for its bulk utilization.

\subsection{Implication of fly ash in the Agricultural sector}

Nowadays, fly ash has become one of the prime sources to enhance the yield of several agriculture fields. Coal having high sulphur content results in the generation of low $\mathrm{pH}$ value ash. The alkaline nature of fly ash commonly originated in India results in higher $\mathrm{pH}$ value, which in turn makes a favorable condition to balance the acidic nature of the soil (Wong and Wong 1986). The elements such as Potassium, Sodium, Zinc, Calcium, Magnesium, and Iron are responsible for the higher production of various crops, whereas the elements like Boron, Selenium, Molybdenum, and other metals lead to undesirable effects (Kachroo et al. 2006; Inam 2007). The concentration of the elements is governed by the particle size means it shows less element for a higher size of the particle (Adriano et al. 1978). Crops, including alfalfa, Bermuda grass, millet, carrot, maize, soybean, rice, wheat, etc. shows an increment in their yield under the influence of fly ash (Furr et al. 1977; Mishra and Shukla 1986a, b; Weinstein et al. 1989). The merit and demerits of the fly ash in agricultural areas can be seen in Table 10.

\subsection{Application of fly ash in geopolymer concrete}

When an alkaline solution reacts with silicon and aluminium, it leads to the formation of a binder generally known as geopolymer (Davidovits 1994). The materials having silicon and aluminium content in non-crystalline form could be used for making geopolymeric material. To activate the geopolymeric process the substantially used activators are $\mathrm{NaOH}, \mathrm{KOH}, \mathrm{Na}_{2} \mathrm{SiO}_{3}, \mathrm{~K}_{2} \mathrm{Si}_{2} \mathrm{O}_{5}$, which are applied alone or in composites (Davidovits 1999; Lloyd and Rangan 2010). The class F fly ash is a more appropriate source to use as a geopolymer than that of class $\mathrm{C}$ fly ash. The geopolymer concrete produced from the fly ash has some valuable properties than that of conventional concrete such as resistance against fire, acid, sulphate, and also has low creep and shrinkage (Hardjito et al. 2005; Duxson et al. 2007). The mixing of mortar produced from the geopolymer should be carried out using a forced mixer in place of a gravity mixer due to the tendency of high viscosity during the initial stage (Teixeira Pinto et al. 2002). Based on the Si/Al ratio, the application of geopolymer is listed in Fig. 4.

\subsection{Application of fly ash in cement concrete}

The pozzolanic properties are generally dependent upon hydrations, which are controlled by the lime percentage and fineness. Interestingly, the fly ash contains both these properties. Fly ash must fulfill the chemical requirement listed 
Table 9 Codal provisions for the successful utilization of fly ash in various areas

\begin{tabular}{|c|c|c|}
\hline Standard codes & Recommendations & $\begin{array}{l}\text { Year of } \\
\text { publica- } \\
\text { tion }\end{array}$ \\
\hline IRC-SP-89 & $\begin{array}{l}\text { More plastic materials should be avoided } \\
\mathrm{LF}^{\mathrm{a}} \text { or } \mathrm{LCF}^{\mathrm{b}} \text { is good for base and sub-base courses } \\
\text { Remove material greater than } 20 \mathrm{~mm} \text { size }\end{array}$ & 2010 \\
\hline IRC-15 & $10 \mathrm{~cm} \mathrm{LFC}^{\mathrm{c}}$ can be used instead of $15 \mathrm{~cm} \mathrm{WBM}$ as a Sub-base & 1970 \\
\hline IRC-60 & $\begin{array}{l}\text { LFC thickness cannot be less than } 10 \mathrm{~cm} \text { (Flexible pavement) } \\
\text { LFC reduces } 20 \%-30 \% \text { thickness compared with granular base } \\
\text { For } 10 \mathrm{~cm} \text { LFC layer, the coarse aggregate size must be smaller than } 40 \mathrm{~mm}\end{array}$ & 1976 \\
\hline IRC-74 & $\begin{array}{l}\text { Compaction time must be within } 45 \mathrm{~min} \text { (summer) and } 1 \mathrm{~h} \text { (winter) } \\
\text { Size of aggregate: Maximum- } 40 \mathrm{~mm} \\
\text { Minimum-20 } \mathrm{mm} \\
\text { Maximum thickness: Smooth wheel roller- }-10 \mathrm{~cm} \\
\text { Vibratory roller- } 15 \mathrm{~cm}\end{array}$ & 1979 \\
\hline IRC-88 & $\begin{array}{l}\text { Minimum thickness of } \mathrm{LFS}^{\mathrm{d}} \text { layer is } 15 \mathrm{~cm} \\
\text { Optimum strength: Lime: Fly ash-1:3 to } 1: 4\end{array}$ & 1984 \\
\hline IRC-SP-58 & $\begin{array}{l}\text { Density of fly ash lower than } 0.9 \mathrm{gm} / \mathrm{cc} \text { is not suitable of embankment fill } \\
\text { Up to } 3 \mathrm{~m} \text { height embankment- density of soil cover must not be less than } \\
1.52 \mathrm{gm} / \mathrm{cc} \\
\text { Fly ash can be compacted using vibratory or static rollers } \\
\text { Under normal serviceability: } \text { FOS }^{\mathrm{e}} \text { should not be less than } 1.25 \text { for embank- } \\
\text { ment construction }\end{array}$ & 2001 \\
\hline IRC-SP-20 & $\begin{array}{l}\text { Fly ash embankment: slope-1 V:1.5H—upto } 3 \mathrm{~m} \\
\text { Minimum dry density after compaction: } 97 \% \mathrm{MDD}^{\mathrm{f}}\end{array}$ & 2002 \\
\hline ASTM-D698 & Road embankment should be compacted within 95 to $100 \%$ of MDD & 2013 \\
\hline
\end{tabular}

$\mathrm{LF}^{\mathrm{a}}$ : Lime Fly ash, $\mathrm{LCF}^{\mathrm{b}}$ : Lime Cement Fly ash, $\mathrm{LFC}^{\mathrm{c}}$ : Lime Fly ash Concrete,

LFS $^{\text {d: Lime Fly ash Soil, FOS }}$ : Factor of Safety, MDD ${ }^{\text {f }}$ : Maximum Dry Density in Table 11 before being utilized in the cement industry. Fly ash is a substitute for cement, but high replacement leads to an increase in the amount of air-entraining admixture (Namagga and Atadero 2009). Cement during hydration generates calcium hydroxide, when it is combined with fly ash results in secondary gelatinous substances, which is an advantageous property of the fly ash (Kocak and Nak 2014). $15 \%-30 \%$ of the cement is commonly replaced by fly ash, on the other side, this can be increased to $30 \%-50 \%$ for large structures (Xu and Shi 2018), where an early gain of strength is not the primary concern. Cross et al. (2005) observed the compressive strength of fly ash based concrete at the age of 2 days, 28 days, 1 year corresponds to 20, 33, $55 \mathrm{MPa}$, where the slump and setting time of the concrete used were 102-216 mm and 120 minutes respectively. The demerits of fly ash can be eliminated with the external additives that increase the benefits of its applications in the long term, which have been discussed in Table 12.

\subsection{Initiatives for mass utilization of fly ash}

In India, most of the steps were taken for the utilization of fly ash in the early stages, but it was not successful at that point of time. The pozzolana portland cement (PPC) was first manufactured in India in 1967 whose production decreases due to the lack of awareness, the absence of long term study, the dominance of ordinary portland cement (OPC), etc. The PPC production increases in 1997 and now a days, it is commonly available because of the government initiatives and high demand. Their utilization must be as high as possible to eliminate the pollution caused by fly ash and to save the environment. To promote its utilization, the Indian Government has taken several initiatives/missions out of which the first mission is named as Fly Ash Mission (FAM). FAM was launched in 1994 with the collaboration of the Department of Science \& Technology, Ministry of Power, and Ministry of Environment and Forests. Technology Information, Forecasting \& Assessment Council was made for the implementation of the above mentioned mission projects (Kumar et al. 2005). In addition, an institution named as a Centre for Fly Ash Research and Management (C-FARM) was made, which is responsible to give all kinds of technical support for different applications of fly ash.

Except this, the government has started an awareness program to be conducted by national thermal power stations, which gives the information to the public regarding the utilization of fly ash in different sectors. Much more research centers are there in India, which are working to make fly ash as a new construction material. 


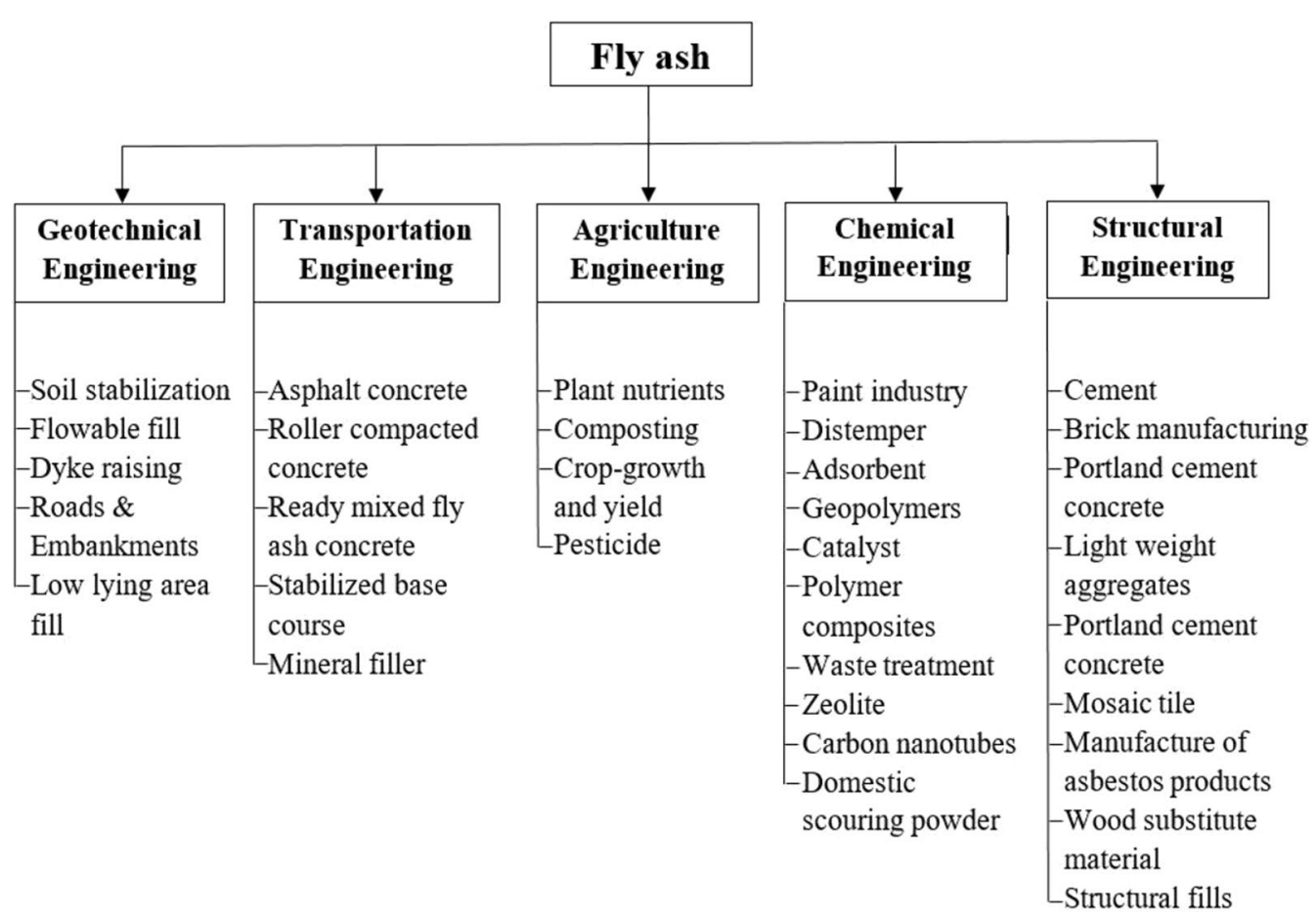

Fig. 3 Representation of fly ash applications in various areas of engineering

\section{Shortcomings in the application of fly ash}

The most general difficulties faced during the application of fly ash are arising due to its light weight, disposal techniques, and weather conditions. Some of the unavoidable issues are listed below:

(1) The thermal power stations primarily adopt wet disposal techniques in India (BIS 10153 (1982)). In this process, fly ash and bottom ash are mixed in the form of slurry, which cannot be used for the production of cement.

(2) The physiochemical properties of the fly ash are influenced by the coal used, combustion process, and disposal systems. Because of this, every power plant has dissimilar properties, which creates problems in its utilization (Fly ash resource centre, Odisha).

(3) During cold-weather conditions the pond ash site generally experiences excessive moisture content, which creates problems during the compaction. Also, it is challenging to maintain the moisture near the optimum moisture content (GE:0-S005 (2006)).

(4) Transportation of fly ash in summer when it is in dry condition leads to spillage nuisance whereas, in wet conditions, it has a tendency to flow from the opening of the dumper (GE:0-S005 (2006)).

(5) In summer, the rate of loss of water from the compacted layer is very high and this can be eliminated by increas- ing the thickness of the fly ash layer from 150 to 300 $\mathrm{mm}$.

\section{Future scopes of mass utilization of fly ash}

The cement and brick industries are the two primary sources of the utilization of fly ash, which accommodate a significant amount of fly ash. In India, its generation exceeds 200 million tonnes; therefore, it is very difficult to utilize all the generated ash. The application area of fly ash must widen for its $100 \%$ utilization. The present replacement of fly ash in cement has been restricted to $15 \%-25 \%$ that can be increased to $50 \%-60 \%$ using mechanical activation of fly ash without compromising the quality of cement (Kumar et al. 2007). Including the mechanical activation, the fly ash products must be examined for their durability, engineering performance, and structural application that can be considered as a future outlook. Along with its applications, fly ash can be exported to the neighboring countries from the nearby thermal power stations like India exports 3 million tonnes of fly ash to Bangladesh for the production of cement. In recent years the application of fly ash has increased in many areas such as self-compacting concrete, fertilizer, embankment fill, dyke raising, wood substitutes, etc. Some of the new products/applications of the fly ash should be 
considered in large scale and a few of them are discussed briefly in the following sections.

(1) Geopolymer: It is produced by the addition of an alkali activator (Sodium silicate or Sodium hydroxides) into the fly ash. The concrete produced from this geopolymer shows good strength and can be used as an alternate source in the construction industry (Singh 2018). It can also be used in fire resistant adhesive, fire resistant composites, thermal insulation, etc. Geopolymer concrete is the recent development of the ash product and is considered as an ecofriendly substitute of the conventionally used concrete. Being a new product, it has not been explored much in terms of durability, long term aspect, and structural application point of view. Further research is required for the determination of the optimum values of curing temperature $\&$ duration, and concentration of $\mathrm{NaOH}$, as well as its mechanical properties at ambient temperature. Also, geopolymer concrete must be investigated for a better mix proportioning/design procedure so that a good quality of concrete can be produced.

(2) Ceramic microspheres: Ceramic microspheres are very small size particles having spherical shapes. The spherical shape is responsible for their utilization in various products like mastic, coatings, paint as filler, fiberglass, plastic and rubber products, mining explosives, etc. This shape requires a very little amount of resin which reduces the overall cost. The existence of cenospheres and plerosphere results in the dominance of spherical particles in fly ash.

(3) Zeolites: It is available naturally and can also be produced artificially by using fly ash. It can sustain very high temperatures and pressure. The main application of zeolites is under water filters and water softeners based on the ion exchange process. It generally consists of aluminosilicates; if the alumina content is more then it will attract polar molecules, whereas, for high silica content, the attraction towards non-polar molecules will be more. It can also be used as solar heat storage, catalysts, and sorbents, etc.

(4) Adsorbent: The presence of high porosity, high specific surface area, and wide particle size in fly ash make it suitable for the use as a low cost adsorbent (Mohan and Gandhimathi 2009). Fly ash has excellent adsorption capacity to eliminate the pollutants from the air and water like volatile organic compounds (VOC), nitrogen oxides, sulfur dioxide, and heavy metals, etc. The presence of silica, alumina, and unburned carbon in the fly ash is responsible for its porous structure (silica, activated carbon, zeolite) that is used for the $\mathrm{CO}_{2}$ adsorption (Dindi et al. 2019). The $\mathrm{CO}_{2}$ adsorption and its utilization has been rarely inspected, and also there is 


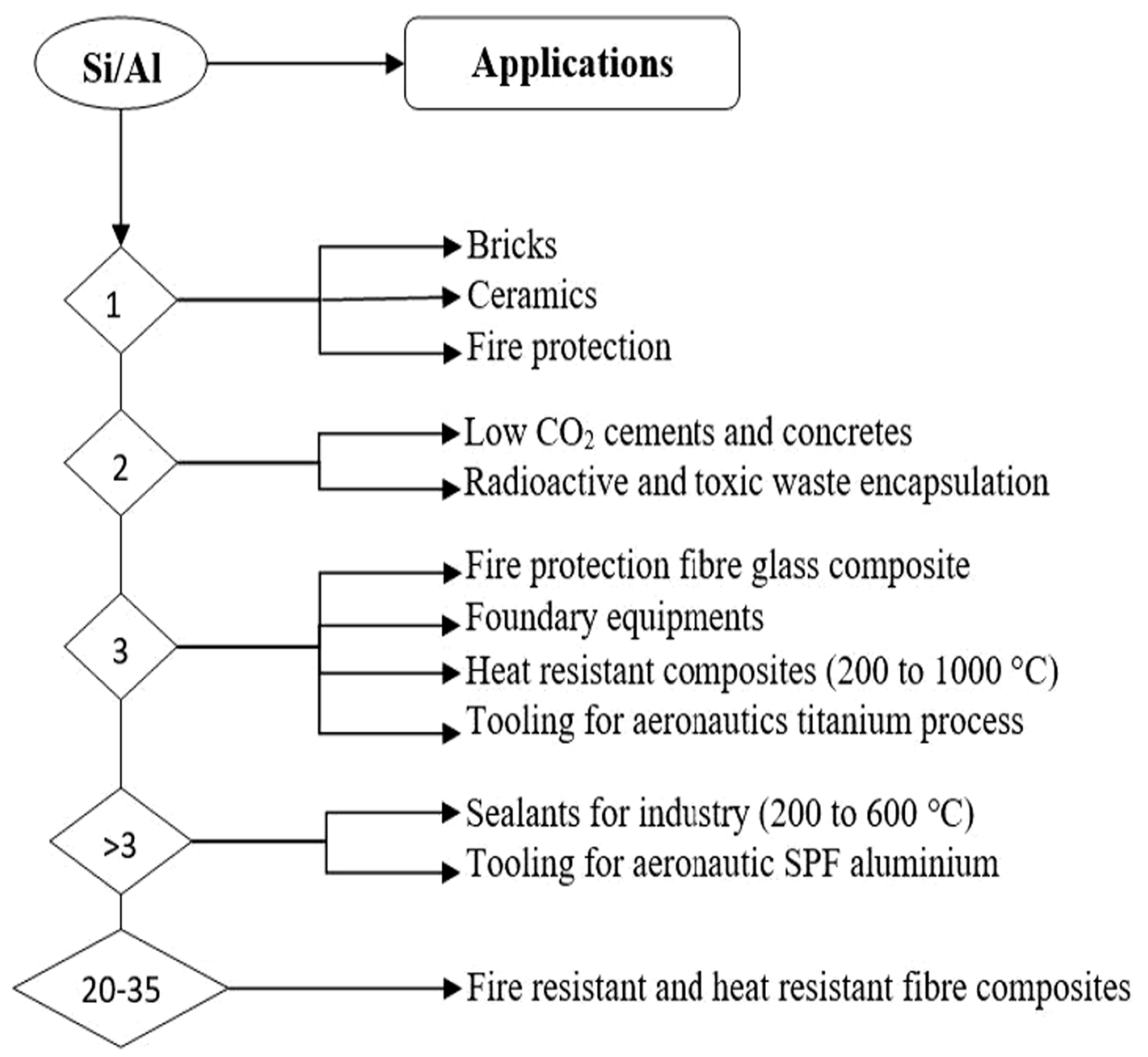

Fig. 4 Representation of geopolymer application on the basis of Si/Al ratio (Davidovits 1994)

Table 11 Chemical requirements of fly ash

\begin{tabular}{llll}
\hline Characteristic & & $\begin{array}{l}\text { Requirement } \\
\text { Siliceous Fly ash }\end{array}$ & $\begin{array}{l}\text { Calcare- } \\
\text { ous Fly } \\
\text { ash }\end{array}$ \\
\hline $\mathrm{SiO}_{2}+\mathrm{Al}_{2} \mathrm{O}_{3}+\mathrm{Fe}_{2} \mathrm{O}_{3}$ & $\mathrm{Min}$ & 70 & 50 \\
$\mathrm{SiO}_{2}$ & $\mathrm{Min}$ & 35 & 25 \\
$\mathrm{MgO} \mathrm{Max}$ & 5.0 & 5.0 \\
$\mathrm{SO}_{3}$ & $\mathrm{Max}$ & 5.0 & 5.0 \\
$\mathrm{Na}_{2} \mathrm{O}$ & $\mathrm{Max}$ & 1.5 & 1.5 \\
$\mathrm{Total}$ chlorides & Max & 0.05 & 0.05 \\
Loss of Ignition & Max & 7.0 & 7.0 \\
\hline
\end{tabular}

Note: Represents in percent by mass

limited study on high performance $\mathrm{CO}_{2}$ utilization catalysts from the fly ash. The adsorption of VOC from the
Table 12 Favorable and unfavorable properties of fly ash (Berryman et al. 2005; Rodriguez 2019)

\begin{tabular}{ll}
\hline Advantage & Disadvantage \\
\hline Permeability reduction & Gradual strength gain \\
High workability & Difficult to use other than summer \\
Low heat of hydration & High use of air-entraining admixture \\
Low $\mathrm{CO}_{2}$ emissions & High salt scaling \\
Low shrinkage & \\
\hline
\end{tabular}

air and the heavy metals from waste water employing fly ash nanofiber membrane needs further investigation for its better understanding. It is evident from the past studies that the heavy metals like $\mathrm{Cu}^{2+} \& \mathrm{Ni}^{2+}$ can be effectively removed by using fly ash and activated carbon, but more studies should be done for investigating its effect on the other heavy metals.

(5) Mesoporous silica: It is composed of a solid structure having a large surface area due to its porous structure. Since fly ash has high silica content, it acts as a better source for the mesoporous silica production. It is used 
in target drug delivery systems, thermal energy storage, biosensors, and imaging, etc.

Despite numerous applications of fly ash in civil engineering construction, its $100 \%$ utilization is yet to be achieved. In addition, it has other applications like as composite material, sources of other compounds, adsorbents, etc. Therefore, it is essential to expand its application not only in civil engineering but also in other engineering as well. Fly ash represents as a source of aluminium due to the presence of mullite and rare earth metals ( $\mathrm{La}, \mathrm{Nd}, \mathrm{Tb}, \mathrm{yb}$, $\mathrm{Tm}$, etc.). This area has a wide scope of research to portray fly ash application in practical use. Similarly, it also be used in combination with other materials, insulating materials, carbon nanotubes, polyester or polyethylene terephthalate (PET) resin, and extraction of elements that exists at the initial stage of research. The complete phenomenon of waste water treatment and its separation with final utilization in the saturated form must be explored independently for successful applications. Fly ash contains radionuclides such as ${ }^{226} \mathrm{Ra},{ }^{232} \mathrm{Th}$, and ${ }^{40} \mathrm{~K}$ those are harmful properties, hence it is significant to study the radiological properties of the fly ash and fly ash derived products (Temuujin et al. 2019). The radiological characteristics must be checked prior to the application because it significantly depends on the radioactive elements. Further research is required for the determination of all the radioactive elements present in the fly ash. Consequently, from the above discussion, this can be deduced that fly ash is a new material for various applications, and for higher acceptance, it required a large set of the laboratory as well as field studies. So that its behavior under different conditions can be observed, which will help in the selection of appropriate applications as per its nature.

\section{Conclusions}

Fly ash has been produced on a very large scale whose disposal required huge land and repeated dumping creates a nuisance at the disposal point. It has very wide application in the engineering/non-engineering activities. Fly ash has some unique properties, which demarcate its applications from the other available coal ash. These unique properties are spherical shape, self-cementing or pozzolanic property, lightweight by virtue of which it shows some advantageous properties in cement and concrete. However, their applications in cement/concrete are restricted to some limits. Hence, its utilization should be given wide areas of application. The utilization of fly ash must be given high attention towards the application in other areas such as asphalt concrete, geopolymer concrete, ground improvement, agricultural sector, roller compacted concrete, brick, etc. that will reduce the available accumulated/produced ashes and also it will decrease all the harmful effects on the environment. These all collective efforts evolve fly ash as a new construction material among other coal ash.

Acknowledgements Authors are grateful to Department of Science and Technology, Government of India for providing financial assistance.

Author's contributions AKR had investigated the detailed physiochemical properties of Indian fly ash and its potential application in civil engineering field as a part of the Ph.D. dissertation. SM had given the research idea, helped in drafting the manuscript. All authors read and approved the final manuscript.

Funding Science and Engineering Research Board (ECR/2015/000580).

Availability of data and materials All data and materials used during the study appear in the submitted article.

\section{Declaration}

Competing interests The authors declare that they have no competing interests.

Open Access This article is licensed under a Creative Commons Attribution 4.0 International License, which permits use, sharing, adaptation, distribution and reproduction in any medium or format, as long as you give appropriate credit to the original author(s) and the source, provide a link to the Creative Commons licence, and indicate if changes were made. The images or other third party material in this article are included in the article's Creative Commons licence, unless indicated otherwise in a credit line to the material. If material is not included in the article's Creative Commons licence and your intended use is not permitted by statutory regulation or exceeds the permitted use, you will need to obtain permission directly from the copyright holder. To view a copy of this licence, visit http://creativecommons.org/licenses/by/4.0/.

\section{References}

Abbas S, Saleem MA, Kazmi SM, Munir MJ (2017) Production of sustainable clay bricks using waste fly ash: mechanical and durability properties. J Build Eng 14:7-14

Adriano DC, Woodford TA, Ciravolo TG (1978) Growth and elemental composition of corn and bean seedlings as influenced by soil application of coal ash 1. J Environ Qual 7:416-421

Ahmaruzzaman M (2010) A review on the utilization of fly ash. Prog Energy Combust Sci 36:327-363

Alam J, Akhtar MN (2011) Fly ash utilization in different sectors in Indian scenario. Int J Emerg Trends Eng Dev 1:1-14

Andrade A, Coenegracht YA, Hollman GG, Janssen-Jurkovicova M, Pietersen HS, Vriend SP, Schuiling RD (1989) Leaching characteristics of fly ash after four years of natural weathering. MRS Online Proceedings Library Archive 178

Antiohos S, Tsimas S (2005) Investigating the role of reactive silica in the hydration mechanisms of high-calcium fly ash/cement systems. Cem Concr Compos 27:171-181

Arvaniti EC, Juenger MC, Bernal SA, Duchesne J, Courard L, Leroy S, Provis JL, Klemm A, De Belie N (2015) Determination of particle size, surface area, and shape of supplementary 
cementitious materials by different techniques. Mater Struct 48:3687-3701

ASTM C 311-07 (2007) Standard Test Methods for Sampling and Testing Fly Ash or Natural Pozzolans forUse in Portland-Cement Concrete, Annual Book of ASTM Standards, ASTM International, West Conshohocken, PA

ASTM D 698-2000 (1995) Test Method for Laboratory Compaction Characteristics of Soils Using Standard Effort. Annual Book of ASTM Standards 4

ASTM E1861 (1997) Standard Guide for Use of Coal Combustion ByProducts in Structural Fills. American Society for Testing and Materials, West Conshohocken, Pennsylvania

ASTM C618-03 (2003) Standard specification for coal fly ash and raw or calcined natural pozzolan for use in concrete. In American society for testing and materials. West Conshohocken, PA, USA: ASTM international

Awang AR, Marto A, Makhtar AM (2012) Morphological and strength properties of Tanjung Bin coal ash mixtures for applied in geotechnical engineering work. Int J Adv Sci Eng Inf Technol 2:168-175

Baba A, Gurdal G, Sengunalp F (2010) Leaching characteristics of fly ash from fluidized bed combustion thermal power plant: case study: Çan (Çanakkale-Turkey). Fuel Process Technol 91:1073-1080

Bărbuţă M, Harja M, Baran I (2010) Comparison of mechanical properties for polymer concrete with different types of filler. J Mater Civ Eng 22:696-701

Basu M, Pande M, Bhadoria PBS, Mahapatra SC (2009) Potential fly-ash utilization in agriculture: a global review. Prog Nat Sci 19:1173-1186

Behr-Andres CB, Hutzler NJ (1994) Characterization and use of fluidized-bed-combustion coal ash. J Environ Eng 120:1488-1506

Berryman C, Zhu J, Jensen W, Tadros M (2005) High-percentage replacement of cement with fly ash for reinforced concrete pipe. Cem Concr Res 35:1088-1091

Bhanarkar AD, Gavane AG, Tajne DS, Tamhane SM, Nema P (2008) Composition and size distribution of particules emissions from a coal-fired power plant in India. Fuel 87:2095-2101

Bhatt A, Priyadarshini S, Mohanakrishnan AA, Abri A, Sattler M, Techapaphawit S (2019) Physical, chemical, and geotechnical properties of coal fly ash: a global review. Case Stud Constr Mater 11:00263

Bijen JMJM (1986) Manufacturing processes of artificial lightweight aggregates from fly ash. Int J Cem Compos Lightweight Concr 8:191-199

BIS 10153 (1982) Guidelines for utilization and disposal of fly ash

BIS 3812-Part2 (2013) Pulverized fuel ash - specification

Blissett RS, Rowson NA (2012) A review of the multi-component utilisation of coal fly ash. Fuel 97:1-23

Bouzoubaa N, Zhang MH, Bilodeau A, Malhotra VM (1997) The effect of grinding on the physical properties of fly ashes and a Portland cement clinker. Cem Concr Res 27:1861-1874

British Standard, EN450 (2005). Fly ash for concrete - Part 1: Definition, specifications and conformity criteria. Publication, London, UK

Cabrera JG, Gray MN (1973) Specific surface, pozzolanic activity and composition of pulverized-fuel ash. Fuel 52:213-219

Cao DZ, Selic E, Herbell JD (2008) Utilization of fly ash from coalfired power plants in China. J Zhejiang Univ Sci A 9:681-687

Chand P, Kumar A, Gaur A, Mahna SK (2009) Elemental analysis of ash using X-ray fluorescence technique. Asian J Chem $21: 220-224$

Chandra A (2009) Some investigations on fly ash resistivity generated in Indian power plants. In: Electrost precip. Springer, Berlin: pp 399-405
Chang AC, Lund LJ, Page AL, Warneke JE (1977) Physical properties of fly ash-amended soils. J Environ Qual 6(3):267-270

Chatterjee AK (2011) Indian fly ashes: Their characteristics and potential for mechano-chemical activation for enhanced usability. J Mater Civ Eng 23:783-788

Chen CY, Bullen AGR, Elnaggar HA (1977) Permeability and related principles of coal refuse. Transp Res Rec 640:49-52

Chengfeng Z, Qiang Y, Jun Ming S (2005) Characteristics of particulate matter from emissions of four typical coal-fired power plants in China. Fuel Proc Technol 86:757-768

Chikkatur AP, Sagar AD, Sankar TL (2009) Sustainable development of the Indian coal sector. Energy 34:942-953

Chindaprasirt P, Homwuttiwong S, Sirivivatnanon V (2004) Influence of fly ash fineness on strength, drying shrinkage and sulfate resistance of blended cement mortar. Cem Concr Res 34:1087-1092

Chindaprasirt P, Jaturapitakkul C, Sinsiri T (2005) Effect of fly ash fineness on compressive strength and pore size of blended cement paste. Cem Concr Compos 27:425-428

Chindaprasirt P, Rattanasak U, Taebuanhuad S (2013) Resistance to acid and sulfate solutions of microwave-assisted high calcium fly ash geopolymer. Mater Str 46(3):375-381

Choi SK, Lee S, Song YK, Moon HS (2002) Leaching characteristics of selected Korean fly ashes and its implications for the groundwater composition near the ash disposal mound. Fuel 81:1083-1090

Coal ash in India - A compendium of Disasters, Environmental and Health Risks (July 2020) - Health Energy Initiative India

Consoli NC, da Rocha CG, Maghous S (2016) Strategies for developing more sustainable dosages for soil-coal fly ash-lime blends. J Mater Civ Eng 28:04016130

Consoli NC, Rosa AD, Saldanha RB (2011) Variables governing strength of compacted soil-fly ash-lime mixtures. J Mater Civ Eng 23:432-440

Cope F (1962) The development of a soil from an industrial waste ash. Trans. Int. Soc. Soil Sci. Commn IV, V, Palmerston, New Zealand: 859-863

Cross D, Stephens J, Vollmer J (2005) Structural applications of 100 percent fly ash concrete. Montana State University, Bozeman

Das SC, Pakrashi S (1990) Behaviour of lime stabilised Titagarh PFA through laboratory tests. J Inst Eng India Civil Eng Div 70:181-186

Das SK (2018) Parametric study of flyash based geopolymer concrete. Int J Eng Technol 7:196-198

Das SK, Yudhbir (2005) Geotechnical characterization of some Indian fly ashes. J Mater Civ Eng 17:544-552

Davidovits J (1994) High-alkali cements for 21st century concretes in concrete technology, past, present and future, proceedings of V. Mohan Malhotra Symposium, Editor: P. Kumar Metha, ACI SP-144:383-397

Davidovits J (1999) Chemistry of geopolymeric systems, terminology. Geopolymer 99:9-39

Davison RL, Natusch DF, Wallace JR, Evans CA Jr (1974) Trace elements in fly ash. Dependence of concentration on particle size. Environ Sci Technol 8:1107-1113

Dayal U, Chandra S, Bohra NC (1989) Geotechnical investigation of ash properties for dyke construction at Ramagundam super thermal power project. IIT, Kanpur

Dermatas D, Meng X (2003) Utilization of fly ash for stabilization/ solidification of heavy metal contaminated soils. Eng Geol 70:377-394

Dhadse S, Kumari P, Bhagia LJ (2008) Fly ash characterization, utilization and Government initiatives in India - a review

Diaz EI, Allouche EN, Eklund S (2010) Factors affecting the suitability of fly ash as source material for geopolymers. Fuel 89:992-996 
DiGioia AM, Nuzzo WL (1972) Fly ash as structural fill. J Power Div 98:77-92

Dinakar P, Reddy MK, Sharma M (2013) Behaviour of self compacting concrete using Portland pozzolana cement with different levels of fly ash. Mater Des 46:609-616

Dindi A, Quang DV, Vega LF, Nashef E, Abu-Zahra MR (2019) Applications of fly ash for $\mathrm{CO} 2$ capture, utilization, and storage. $\mathrm{J} \mathrm{CO} 2$ Util 29:82-102

Duan P, Yan C, Zhou W (2017) Compressive strength and microstructure of fly ash based geopolymer blended with silica fume under thermal cycle. Cem Concr Compos 78:108-119

Dudas MJ, Warren CJ (1987) Submicroscopic model of fly ash particles. Geoderma 40:101-114

Duxson P, Provis JL, Lukey GC, van Deventer JSJ (2007) The role of inorganic polymer technology in the development of green concrete. Cem Concr Res 37:1590-1597

Ellis WE, Riggs EH, Butler WB (1991) Comparative results of utilization of fly ash, silica fume and GGBFS in reducing the chloride permeability of concrete in durability of concrete. Second international conference. August 4-9, 1991, Montreal, Canada: $126-23$

Energy Statistics (2019) Report on energy statistics - twenty sixth issue: Ministry of Statistics and Programme Implementation, Government of India, New Delhi.

Environmental Protection Agency (EPA) (April 2005) Federal Highway Administration (FHWA). Using coal ash in highway construction - a guide to benefits and impacts. Report nr EPA-530-K-002:ID:151

Erdoğdu K, Türker P (1998) Effects of fly ash particle size on strength of Portland cement fly ash mortars. Cem Concr Res 28:1217-1222

Eze CP, Nyale SM, Akinyeye RO, Gitari WM, Akinyemi SA, Fatoba OO, Petrik LF (2013) Chemical, mineralogical and morphological changes in weathered coal fly ash: a case study of a brine impacted wet ash dump. J Environ Manag 129:479-492

Fan M, Brown RC, Wheelock TD, Cooper AT, Nomura M, Zhuang Y (2005) Production of a complex coagulant from fly ash. Chem Eng J 106:269-277

Fatih T, Umit A (2001) Utilization of fly ash in manufacturing of building bricks. In: International ash utilization symposium. Center for applied energy research, University of Kentucky Paper, 13

Ferreira C, Ribeiro A, Ottosen L (2003) Possible applications for municipal solid waste fly ash. J Hazard Mater 96:201-216

FHWA-IF-03-019 (2003) Fly ash facts for highway engineers, American Coal Ash Association, Washington DC

Fisher GL, Natusch DFS (1979) Size dependence of the physical and chemical properties of coal fly ash. In: Analytical methods for coal and coal products, Academic Press: 489-541

Fisher GL, Chang DPY, Brummer M (1976) Fly ash collected from electrostatic precipitators: microcrystalline structures and the mystery of the spheres. Science 192:553-555

Fisher GL, Prentice BA, Silberman D, Ondov JM, Biermann AH, Ragaini RC, McFarland AR (1978) Physical and morphological studies of size-classified coal fly ash. Environ Sci Technol 12:447-451

Freeman E, Gao YM, Hurt R, Suuberg E (1997) Interactions of carboncontaining fly ash with commercial air-entraining admixtures for concrete. Fuel 76:761-765

Fulekar MH, Dave JM (1986) Disposal of fly ash—an environmental problem. Int J Environ Stud 26:191-215

Furr AK, Parkinson TF, Hinrichs RA, Van Campen DR, Bache CA, Gutenmann WH, St. John Jr LE, Pakkala IS, Lisk DJ (1977) National survey of elements and radioactivity in fly ashes. Absorption of elements by cabbage grown in fly ash-soil mixtures. Environ Sci Technol 11:1194-1201
Gang Xu, Shi X (2018) Characteristics and applications of fly ash as a sustainable construction material: a state-of-the-art review. Resour Conserv Recycl 136:95-109

Ghazy A, Bassuoni MT, Shalaby A (2016) Nano-modified fly ash concrete: a repair option for concrete pavements. ACI Mater $\mathbf{J}$ 113:231-242

Grzeszczyk S, Lipowski G (1997) Effect of content and particle size distribution of high-calcium fly ash on the rheological properties of cement pastes. Cem Concr Res 27:907-916

Gullu H (2014) Factorial experimental approach for effective dosage rate of stabilizer: application for fine-grained soil treated with bottom ash. Soils Found 54:462-477

Hanif A, Lu Z, Li Z (2017) Utilization of fly ash cenosphere as lightweight filler in cement-based composites-a review. Constr Build Mater 144:373-384

Haquin G (2008) Natural radioactivity and radon in building materials. In 12 th international congress of the international radiation protection association, Buenos Aires

Hardjito D, Rangan BV (2005) Development and properties of lowcalcium fly ash-based geopolymer concrete. Curtin University of Technology

Hasan M, Khan MA, Alam J (2014) Permeability characteristic of fly ash treated with bentonite. In Proceedings of Indian geotechnical conference IGC, December: 18-22

Hauser VL (1978) Seepage control by particle size selection. Trans Am Soc Agric Eng 21:691-0695

Hemmings RT, Berry EE (1987) On the glass in coal fly ashes: recent advances. MRS Online Proceedings Library Archive 113

Hirajima T, Petrus HTBM, Oosako Y, Nonaka M, Sasaki K, Ando T (2010) Recovery of cenospheres from coal fly ash using a dry separation process: separation estimation and potential application. Int J Miner Process 95:18-24

Hower JC, Groppo JG, Graham UM, Ward CR, Kostova IJ, MarotoValer MM, Dai S (2017) Coal-derived unburned carbons in fly ash: a review. Int J Coal Geol 179:11-27

Hower JC, Senior CL, Suuberg EM, Hurt RH, Wilcox JL, Olson ES (2010) Mercury capture by native fly ash carbons in coal-fired power plants. Prog Energy Combust Sci 36:510-529

https://theconstructor.org/building/fly-ash-properties-types-mecha nism/26654/. Accessed 6 Jan 2020

https://rmrc.wisc.edu/coal-fly-ash/. Accessed 6 Jan 2020

Inam A (2007) Response of methi to nitrogen and flyash supplemented as a source of nutrients. Pollut Res 26:43

Issues in utilization of ash by thermal power plants in the country, Journal of Government Audits and Accounts, 3 August 2015. (https://cag.gov.in/sites/default/files/cag_pdf/august-2015/issuesin-utilization-of-ash-by-thermal-power-plants-in-the-country. html). Accessed 6 Jan 2020

Japanese Industrial Standard (JIS) (1997) JIS R 5201; JIS: Tokyo, Japan

Jaturapitakkul C, Kiattikomol K, Songpiriyakij S (1999) A study of strength activity index of ground coarse fly ash with Portland cement. Sci Asia 25:223-229

Jędrusik M, Świerczok A (2011) The influence of unburned carbon particles on electrostatic precipitator collection efficiency. J Phys Conf Ser 301:012009

Jones DR (1995) The leaching of major and trace elements from coal ash. In: Environmental aspects of trace elements in coal. Springer, Dordrecht: 221-262

Joshi SV, Kadu MS (2012) Role of alkaline activator in development of eco-friendly fly ash based geo polymer concrete. Int J Environ Sci Dev 3:417

Kachroo D, Dixit AK, Balp AS (2006) Influence of crop residue, flyash and varying starter dosages on growth, yield and soil characteristics in rice (Oryzasativa)-Wheat (Triticum aestivum) cropping 
system under irrigated conditions of Jammu region. Indian $\mathbf{J}$ Agric Sci 76:3-6

Kamruzzaman M, Islam SMZ, Nizamud-Doulah SM, Jingkaojai S (2003) Performance of pulverised fuel ash in cement concrete. In CONMAT 2003: International workshop and conference on construction and materials: $539-548$

Kaniraj SR, Gayathri V (2004) Permeability and consolidation characteristics of compacted fly ash. J Energy Eng 130:18-43

Karasawa A, Suda S, Naito H, Fujiwara H (2003) Application of fly ash to concrete paving block. In: Proceedings of the 7th international conference on concrete block paving (Pave Africa), ISBN Number: 0-958-46091-4

Karunakaran M, Sivakimar P, Chira N (2019) Electrostatic precipitator in ash removal system: a comprehensive review. Int J Innov Technol Explor Eng 8:321-324

Khanra S, Mallick D, Dutta SN, Chaudhuri SK (1998) Studies on the phase mineralogy and leaching characteristics of coal fly ash. Water Air Soil Pollut 107:251-275

Kiattikomol K, Jaturapitakkul C, Songpiriyakij S, Chutubtim S (2001) A study of ground coarse fly ashes with different finenesses from various sources as pozzolanic materials. Cem Concr Compos 23:335-343

Kim B, Prezzi M, Salgado R (2005) Geotechnical properties of fly and bottom ash mixtures for use in highway embankments. J Geotech Geoenviron Eng 131:914-924

Kishor P, Ghosh AK, Kumar D (2010) Use of fly ash in agriculture: a way to improve soil fertility and its productivity. Asian $\mathrm{J}$ Agric Res 4:1-14

Kocak Y, Nas S (2014) The effect of using fly ash on the strength and hydration characteristics of blended cements. Constr Build Mater 73:25-32

Kocuvan (1979) A Proposal for classification of fly ashes. In: Proceedings 5th international ash utilization symposium, METC/ SP-79/10: 215-219

Kolay PK, Singh DP (2001) Physical, chemical, mineralogical, and thermal properties of cenospheres from an ash lagoon. Cem Concr Res 31:539-542

Kolbe JL, Lee LS, Jafvert CT, Murarka IP (2011) Use of alkaline coal ash for reclamation of a former strip mine. In World of Coal Ash (WOCA) Conference, USA: 1-15

Kostarelos K, Reale D, Dermatas D, Rao E, Moon DH (2006) Optimum dose of lime and fly ash for treatment of hexavalent chromiumcontaminated soil. Water Air Soil Pollut Focus 6(1-2):171-189

Kumar A, Mandal JN (2016) Triaxial behaviour of Jute reinforced fly ash. In: Indian geotechnical conference IGC-2016, December, Chennai, India: 15-16

Kumar R, Kumar S, Mehrotra SP (2007) Towards sustainable solutions for fly ash through mechanical activation. Resour Conserv Recycl 52:157-179

Kumar D, Kumar N, Gupta A (2014a) Geotechnical properties of fly ash and bottom ash mixtures in different proportions. Int J Sci Res 75:1487-1494

Kumar D, Gupta A, Kumar N (2014b) Some geotechnical properties of coal fly ash and sand mixtures with different ratio using in highway \& embankments. Gl J Res Eng 14:5

Kumar S, Upadhyay SN (1983 November) Atmospheric emissions from thermal power plants in India. In: Proceedings symposium on air pollution control: 119-131

Kumar S, Gandhi BK, Mohapatra SK (2014) Performance characteristics of centrifugal slurry pump with multi-sized particulate bottom and fly ash mixtures. Part Sci Technol 32:466-476

Kumar S, Singh G, Mohapatra SK (2016) An assessment of the physi$\mathrm{cal}$, mineral, and rheological properties of fly ash for stowing in coal mines. Energy Sources Part A Recov Utiliz Environ Effects 38:2955-2962
Kumar S, Singh J, Mohapatra SK (2018) Role of particle size in assessment of physico-chemical properties and trace elements of Indian fly ash. Waste Manage Res 36:1016-1022

Kumar V, Singh G, Rai R (2005) Fly ash: a material for another green revolution. Fly Ash India, New Delhi

Kutchko BG, Kim AG (2006) Fly ash characterization by SEM-EDS. Fuel 85:2537-2544

Lee SH, Sakai E, Daimon M, Bang WK (1999) Characterization of fly ash directly collected from electrostatic precipitator. Cem Concr Res 29:1791-1797

Li G, Wu X (2005) Influence of fly ash and its mean particle size on certain engineering properties of cement composite mortars. Cem Concr Res 35:1128-1134

Li XG, Chen QB, Huang KZ, Ma BG, Wu B (2012) Cementitious properties and hydration mechanism of circulating fluidized bed combustion (CFBC) desulfurization ashes. Constr Build Mater 36:182-187

Lin DF, Lin KL, Luo HL (2007) A comparison between sludge ash and fly ash on the improvement in soft soil. J Air Waste Manag Assoc 57:59-64

Lingling X, Wei G, Tao W, Nanru Y (2005) Study on fired bricks with replacing clay by fly ash in high volume ratio. Constr Build Mater 19:243-247

Liu M (2010) Self-compacting concrete with different levels of pulverized fuel ash. Constr Build Mater 24:1245-1252

Lloyd N, Rangan V (2010) Geopolymer concrete with fly ash. In: Proceedings of the second internationalconference on sustainable construction materials and technologies. UWM Center for ByProducts Utilization: 1493-1504

Mehta PK (1989) Pozzolanic and cementitious by-products in concrete-Another look. Proc. 3rd lnt. Conf. Fly Ash, Slag, Silica Fume and Natural Pozzolnas in Concrete, Trondheim, Norway pp 1-43

Mehta A, Parate K, Ruprai BS (2013) Stabilization of black cotton soil by fly ash. International Journal of Application or Innovation in Engineering \& Management. Special Issue for National Conference on Recent Advances in Technology and Management for Integrated Growth 2013 (RATMIG 2013). http://www.ijaiem. org/RATMIG-2013/CE\%2010\%20Stabilization\%20of\%20Bla ck\%20Cotton\%20Soil\%20by\%20Fly\%20Ash.pdf

Maier H, Spliethoff H, Kicherer A, Fingerle A, Hein KRG (1994) Effect of coal blending and particle size on NOx emission and burnout. Fuel 73:1447-1452

Malaviya SK, Chatterjee B, Singh KK (1999) Fly ash-An emerging alternative building material: $59-67$

Manocha LM, Ram KA, Manocha SM (2011) Separation of cenospheres from fly ashes by floatation method. Eur Chem Technol J 13:89-95

Marceau ML, Gajda J, VanGeem MG (2002) Use of fly ash in concrete: normal and high volume ranges, PCA R\&D Serial No. 2604, Portland Cement Association, Skokie, Illinois

McCarthy MJ, Dhir RK (1999) Towards maximising the use of fly ash as a binder. Fuel 78:121-132

McCarthy MJ, Dyer TD (2019) Pozzolanas and Pozzolanic materials. Lea's Chemistry of Cement and Concrete: 363

McCrone WC, Delly JG (1973) The particles atlas, 2nd edn. Ann Arbor Science, Ann Arbor: 323-324

McLaren RJ, DiGioia AM (1987) The typical engineering properties of fly ash. In Geotechnical practice for waste disposal'87. ASCE: 683-697

Meyers JF, Pichumani R, Kapples BS (1976) Fly ash as a highway construction material a manual. 76-16 Implementation Package. US Department of Transportation, Federal Highway Administration.

Ministry of power - (CAE2019) Report on fly ash generation at Coal / Lignite based thermal power stations and its utilization in the country for the Year 2019-20. New Delhi, India. 
Mishra DP, Das SK (2010) A study of physico-chemical and mineralogical properties of Talcher coal fly ash for stowing in underground coal mines. Mater Charact 61:1252-1259

Mishra LC, Shukla KN (1986a) Edaphic properties of fly ash from a coal-fired power plant at Kanpur, India. Environ Pollut B 11:55-66

Mishra LC, Shukla KN (1986b) Effects of fly ash deposition on growth, metabolism and dry matter production of maize and soybean. Environ Pollut Ser A Ecol Biol 42:1-13

Misra A (1998) Stabilization characteristics of clays using class C fly ash. Transp Res Rec 1611:46-54

Moghal AAB (2017) State-of-the-art review on the role of fly ashes in geotechnical and geoenvironmental applications. J Mater Civ Eng 29:04017072

Moghal AAB, Sivapullaiah PV (2011) Effect of pozzolanic reactivity on compressibility characteristics of stabilised low lime fly ashes. Geotech Geol Eng 29(5):665-673

Mohan S, Gandhimathi R (2009) Removal of heavy metal ions from municipal solid waste leachate using coal fly ash as an adsorbent. J Hazard Mater 169:351-359

Mollamahmutoğlu M, Yilmaz Y (2001) Potential use of fly ash and bentonite mixture as liner or cover at waste disposal areas. Environ Geol 40:1316-1324

Muhunthan B, Taha R, Said J (2004) Geotechnical engineering properties of incinerator ash mixes. J Air Waste Manag Assoc 54:985-991

Namagga C, Atadero RA (2009) Optimization of fly ash in concrete: High lime fly ash as a replacement for cement and filler material. In World of Coal Ash Conference (WOCA), Lexington, KY, USA

Nayak N, Panda CR (2010) Aluminium extraction and leaching characteristics of Talcher Thermal Power Station fly ash with sulphuric acid. Fuel 89:53-58

Nurwidayati R, Ulum MB, Ekaputri JJ, Suprobo P (2016) Characterization of fly ash on geopolymer paste. Mater Sci Forum 841:118-125

Odler I, Zysk KH (1989) Hydraulic properties of fluidized bed combustion ashes. MRS Online Proceedings Library Archive, 178

Oliveira ML, Ward CR, French D, Hower JC, Querol X, Silva LF (2012) Mineralogy and leaching characteristics of beneficiated coal products from Santa Catarina, Brazil. Int J Coal Geol 94:314-325

Padade AH, Mandal JN (2014) Expanded polystyrene-based geomaterial with fly ash. Int J Geomech 14(6):1-7

Page AL, Bingham FT, Lund LJ, Bradford GR, Elseewi AA (1977) Consequences of trace element enrichment of soils and vegetation from the combustion of fuels used in power generation. Southern California Edison Research and Development Series

Page AL, Elseewi AA, Straughan IR (1979) Physical and chemical properties of fly ash from coal-fired power plants with reference to environmental impacts. In: Residue reviews. Springer, New York: $83-120$

Pal SK, Ghosh A (2010) Influence of physical properties on engineering properties of class F fly ash. In Indian geotechnical conference: 361-364

Pandey VC, Abhilash PC, Upadhyay RN, Tewari DD (2009) Application of fly ash on the growth performance and translocation of toxic heavy metals within Cajanus cajan L.: implication for safe utilization of fly ash for agricultural production. J Hazard Mater $166: 255-259$

Pandian NS (2013) Fly ash characterization with reference to geotechnical applications. J Indian Inst Sci 84:189

Pandian NS, Rajasekhar C, Sridharan A (1998) Studies of the specific gravity of some Indian coal ashes. J Test Eval 26:177-186

Parker DG, Thornton SI, Cheng CW (1977) Permeability of fly ash stabilized soils. In Proceedings of the Conference on Geotechnical
Practices for Disposal of Solid Waste Materials, University of Michigan, Ann Arbor, Michigan, June 13-15.

DG, Thornton SI, Cheng CW (1977) Permeability offly ash stabilized soils. In: Proceedings of the conference on geotechnical practices for disposal of solid waste materials, University of Michigan, Ann Arbor, Michigan, June 13-15

Paulson CAJ (1967) Ramsden AR (1970) Some microscopic features of fly-ash particles and their significance in relation to electrostatic precipitation. Atmos Environ 4:175-185

Paya J, Monzo J, Borrachero MV, Peris-Mora E (1995) Mechanical treatment of fly ashes. Part I: physico-chemical characterization of ground fly ashes. Cem Concr Res 25:1469-1479

Plank CO, Martens DC (1974) Boron availability as influenced by application of fly ash to soil. Soil Sci Soc Am J 38:974-977

Prabakar J, Dendorkar N, Morchhale RK (2004) Influence of fly ash on strength behavior of typical soils. Constr Build Mater 18:263-267

Prakash K, Sridharan A (2009) Beneficial properties of coal ashes and effective solid waste management. Pract Period Hazard Toxic Radioact Waste Manag 13:239-248

Prashanth JP, Sivapullaiah PV, Sridharan A (1998) Compaction curves on volume basis. Geotech Test J 21:58-65

Prashanth JP, Sivapullaiah PV, Sridharan A (2001) Pozzolanic fly ash as a hydraulic barrier in land fills. Eng Geol 60:245-252

Raask E (1968) Cenospheres in pulverized-fuel ash. J Inst Fuel 41:339

Rajak TK, Yadu L, Chouksey SK, Pal SK (2017) Strength characteristics of fly ash stabilized soil embankment and stability analysis using numerical modelling. In Indian geotechnical conference: 14-16.

Rajaram S (1999) Next generation CFBC. Chem Eng Sci 54:5565-5571

Rajasekhar C (1995) Retention and permeability characteristics of clays and clay-fly ash systems subjected to flow of contaminants [Ph.D. thesis], Indian Institute of Science, Bangalore, India

Ratna Prasad R, Darga Kumar N (2015) CBR and strength aspects of fly ash-granular soil mixtures. Int J Eng Res Gen Sci 3:943-953

Raymon S (1961) Pulverized fuel ash as embankment material. Proc Inst Civ Eng 19:515-536

Rees WJ, Sidrak GH (1956) Plant nutrition on fly-ash. Plant and Soil: 141-159

Report No. GE:0-S005 (2006) Study report on use of coal ash in railway embankment. Ministry of railway, Government of India

Report on Characterization of fly ash. Fly Ash Mission (FAM) (2001) - TIFAC, DST, New Delhi

Report on Fly ash utilization in road construction (2015) Fly ash resource center (FARC) State pollution control board, Odisha

Rodriguez J (2019) Uses, Benefits, and Drawbacks of fly ash in construction. The pros and cons of using fly ash in concrete.

Roy RD (1940) A critical study of some Indian coal ashes. Geol Surv India 4:539-548

Roy WR, Griffin RA (1982) A proposed classification system for coal fly ash in multidisciplinary research. J Environ Qual 11:563-568

Rukzon S, Chindaprasirt P, Mahachai R (2009) Effect of grinding on chemical and physical properties of rice husk ash. Int J Miner Metall Mater 16:242-247

Sachan A, Rao K (2010) Permeability of Panki fly ash under stress. Int J Geotech Eng 4(1):63-70

Sadasivan S, Negi BS (1991) Chemical characterisation of fly ash from coal-fired thermal power plants in India. Sci Total Environ 103:151-158

Saha S, Pal SK (2013) Influence of fly ash on unconfined compressive strength of soil and fly ash layers placed successively. Elect J Geotech Eng 18:1593-1602

Sahoo JPS, Yadav S, Kumar V (2010) Strength characteristics of fly ash mixed with lime stabilized soil. In Indian Geotechnical Conference-2010. IGS Mumbai Chapter \& IIT Bombay 
Saikia BK, Ward CR, Oliveira ML, Hower JC, De Leao F, Johnston MN, O'Bryan A, Sharma A, Baruah BP, Silva LF (2015) Geochemistry and nano-mineralogy of feed coals, mine overburden, and coal-derived fly ashes from Assam (North-east India): a multi-faceted analytical approach. Int J Coal Geol 137:19-37

Salunkhe TV, Mandal JN (2014) Behavior of fly ash at different mix ratios with plastic recycled polymers. Int J Res Appl Sci Eng Technol (IJRASET) 2:190-198

Sankar VSR, Niranjan DV (2015) Effect of compaction conditions on the hydraulic and compressibility behaviour of fly ash-bentonite mixtures. IOSR J Mech Civ Eng 12:1-28

Saride S, Avirneni D, Javvadi SCP, Puppala AJ, Hoyos LR (2015) Evaluation of fly ash treated reclaimed asphalt pavement for base/subbase applications. Indian Geotech J 45:401-411

Sarkar A, Rano R, Mishra KK, Mazumder A (2007) Characterization of cenospheres collected from ash-pond of a super thermal power plant. Energy Sourc Part A Recov Utili Environ Effects 30:271-283

Sarkar A, Rano R, Mishra KK, Sinha IN (2005) Particle size distribution profile of some Indian fly ash-acomparative study to assess their possible uses. Fuel Process Technol 86:1221-1238

Sarkar A, Vishwakarma S, Banichul H, Mishra KK, Roy SS (2012) A comprehensive analysis of the particle size and shape of fly ash from different fields of ESP of a super thermal power plant. Energy Sourc Part A Recov Util Environ Effects 34:385-395

Sarkar M, Acharya PK (2006) Use of fly ash for the removal of phenol and its analogues from contaminated water. Waste Manag 26:559-570

Schure M, Soltys PA, Natusch DF, Mauney T (1985) Surface area and porosity of coal fly ash. Environ Sci Technol 19:82-86

Schwarz N, Neithalath N (2008) Influence of a fine glass powder on cement hydration: comparison to fly ash and modeling the degree of hydration. Cem Concr Res 38:429-436

Sharma NK, Swain SK, Sahoo UC (2012) Stabilization of a clayey soil with fly ash and lime: a micro level investigation. Geotech Geol Eng 30:1197-1205

Sharma SK (1997) Environmental issues associated with coal ash. Employ News 21:1-2

Sheng G, Li Q, Zhai J, Li F (2007) Self-cementitious properties of fly ashes from CFBC boilers co-firing coal and high-sulphur petroleum coke. Cem Concr Res 37:871-876

Shil S, Pal DSK (2015) Permeability and Volume Change Behaviour of Soil Stabilized with Fly ash. Int J Eng Res Technol (IJERT) ISSN 2278-0181

Shim YS, Rhee SW, Lee WK (2005) Comparison of leaching characteristics of heavy metals from bottom and fly ashes in Korea and Japan. Waste Manag 25:473-480

Shirai H, Ikeda M, Tanno K (2011) Factors affecting the density and specific surface area (Blaine value) of fly ash from pulverized coal combustion. Energy Fuels 25:5700-5706

Shreya N, Valentim B, Paul B, Guedes A, Pinho S, Ribeiro J, Ward CR, Flores D (2015) Multi-technique study of fly ash from the Bokaro and Jharia coalfields (Jharkhand state, India): a contribution to its use as a geoliner. Int J Coal Geol 152:25-38

Siddique R (2010) Utilization of coal combustion by-products in sustainable construction materials. Resour Conserv Recyl 54:1060-1066

Singh DN (1996) Influence of chemical constituents on fly ash characteristics. In: Proceedings of the Indian geotechnical conference: 227-230

Singh GB, Subramaniam KV (2018) Characterization of Indian fly ashes using different experimental techniques. Indian Concr J 92:10-23
Singh MK, Kumar S, Ratha D (2016) Physiochemical and leaching characteristics of fly and bottom ash. Energy Sourc Part A Recov Util Environ Effects 38:2377-2382

Singh NB (2018) Fly ash-based geopolymer binder: a future construction material. Minerals 8:299

Singh RK, Gupta NC, Guha BK (2012) The leaching characteristics of trace elements in coal fly ash and an ash disposal system of thermal power plants. Energy Sourc Part A Recov Util Environ Effects 34:602-608

Sjöblom R (2014) Classification of ash as hazardous or non-hazardous waste. In: International conference on industrial and hazardous waste management: 02-05 September 2014

Small J A (1976) PhD dissertation, University of Maryland, College Park, MD

Sridharan A, Pandian NS, Srinivasa Rao P (1998) Shear strength characteristics of some Indian fly ashes. Proc Inst Civ Eng Ground Improve 2:141-146

Sridharan A, Pandian NS, Srinivas S (2001) Compaction behaviour of Indian coal ashes. Proc Inst Civ Eng Ground Improve 5:13-22

Sun P, Guo Z (2015) Preparation of steel slag porous sound-absorbing material using coal powder as pore former. J Environ Sci 36:67-75

Supit SW, Shaikh FU, Sarker PK (2014) Effect of ultrafine fly ash on mechanical properties of high volume fly ash mortar. Constr Build Mater 51:278-286

Tan Z, Xiao G (2012) Leaching characteristics of fly ash from Chinese medical waste incineration. Waste Manag Res 30:285-294

Technical EIA Guidance manual for thermal power plants prepared for Ministry of Environment and Forests by IL\&FS Ecosmart, August 2010

Teixeira-Pinto A, Fernandes P, Jalali S (2002 October) Geopolymer manufacture and application-Main problems when using concrete technology. In Geopolymers 2002 International Conference, Melbourne, Australia, Siloxo Pty. Ltd.

Temuujin J, Surenjav E, Ruescher CH, Vahlbruch J (2019) Processing and uses of fly ash addressing radioactivity (critical review). Chemosphere 216:866-882

Tepsri P, Humph A, Yoriya S (2018) High-calcium fly ash recovery from wet-stored condition and its properties. Mater Res Exp 5(11)115506:1-11.

The Health and Environmental Impact of coal mining in Chhattisgarh (November-2017) (https://pfcollectiveindia.files.wordpress.com/ 2017/11/raigarh_report_final-2.pdf)

Thomas MDA (2007) Optimizing the use of fly ash in concrete (Vol. 5420). Skokie, IL: Portland Cement Association.

Thompson A (2008) The current and future nature of combustion ashes. Combustion residues: current, novel and renewable applications: $1-84$

Tiwari SK, Ghiya A (2013) Strength behavior of compacted fly ash, bottom ash and their combinations. Elect J Geotech Eng 18:3085-3106

Tiwari M, Sahu SK, Bhangare RC, Ajmal PY, Pandit GG (2014) Elemental characterization of coal, fly ash, and bottom ash using an energy dispersive X-ray fluorescence technique. Appl Radiat Isot 90:53-57

Torrey S (1978) Coal ash utilization. Fly ash, bottom ash and slag. Coal ash utilization. Fly ash, bottom ash and slag: 370

Tripathy PSM, Mukherjee SN (1997) Perspectives on bulk use of fly ash, CFRI Golden Jubilee Monograph, Allied Publishers Limited: 123

Trivedi A, Sud VK (2004) Collapse behavior of coal ash. J Geotech Geoenviron Eng 130:403-415 
Tsimas S, Moutsatsou-Tsima A (2005) High-calcium fly ash as the fourth constituent in concrete: problems, solutions and perspectives. Cem Concr Compos 27:231-237

Turk K, Karatas M (2011) Abrasion resistance and mechanical properties of self-compacting concrete with different dosages of fly ash/silica fume

Ugurlu A (2004) Leaching characteristics of fly ash. Environ Geol 46:890-895

Ugurlu A, Salman B (1998) Phosphorus removal by fly ash. Environ Int 24(8):911-918

U.S. Environmental Protection Agency, Human and ecological risk assessment of coal combustion wastes. Draft EPA document (2007). https://18.190.132.27/wp-content/uploads/2012/05/ epa-coal-combustion-waste-risk-assessment.pdf. Accessed 6 Jan 2020

Vassilev SV, Vassileva CG (2007) A new approach for the classification of coal fly ashes based on their origin, composition, properties, and behaviour. Fuel 86:1490-1512

Viskochil RK, Handy RL, Davidson DT (1958) Effect of density on strength of lime-flyash stabilized soil. Highw Res Board Bull 183:5-15

Wang MC, Huang CC (1984) Soil compaction and permeability prediction models. J Environ Eng 110:1063-1083

Wang S, Boyjoo Y, Choueib A, Ng E, Wu H, Zhu Z (2005) Role of unburnt carbon in adsorption of dyes on fly ash. J Chem Technol Biotechnol Int Res Process Environ Clean Technol 80:1204-1209

Wang T, Ishida T, Gu R (2018) A comparison of the specific surface area of fly ash measured by image analysis with conventional methods. Constr Build Mater 190:1163-1172

Weinstein LH, Osmeloski JF, Rutzke M, Beers AO, McCahan JB, Bache CA, Lisk DJ (1989) Elemental analysis of grasses and legumes growing on soil covering coal fly ash landfill sites. J Food Saf 9:291-300

Wen LLCJZ, Xin ZJC (2003) Study on physical activation of fly ash. Bulletin of the Chinese Ceramic Society 3
White HJ (1977) Electrostatic precipitation of fly ash. J Air Pollut Control Assoc 27:15-22

Wolfe RW, Gjinolli A (1999) Durability and strength of cement-bonded wood particle composites made from construction waste. For Prod J 49:24-31

Wong JW, Wong MH (1990) Effects of fly ash on yields and elemental composition of two vegetables, Brassica parachinensis and $\mathrm{B}$. chinensis. Agr Ecosyst Environ 30:251-264

Wong MH, Wong JWC (1986) Effects of fly ash on soil microbial activity. Environ Pollut Ser A Ecol Biol 40:127-144

Wu T, Chi M, Huang R (2014) Characteristics of CFBC fly ash and properties of cement-based composites with CFBC fly ash and coal-fired fly ash. Constr Build Mater 66:172-180

Xiao X, Yang H, Zhang H, Lu J, Yue G (2005) Research on carbon content in fly ash from circulating fluidized bed boilers. Energy Fuels 19:1520-1525

Yan K, Gao F, Sun H, Ge D, Yang S (2019) Effects of municipal solid waste incineration fly ash on the characterization of cementstabilized macadam. Constr Build Mater 207:181-189

Yoshimoto N, Hyodo M, Nakata Y, Orense RP, Hongo T, Ohnaka A (2012) Evaluation of shear strength and mechanical properties of granulated coal ash based on single particle strength. Soils Found 52:321-334

Yudhbir HY, Honjo Y (1991) Application of geotechnical engineering to environmental control. Theme Lect 5:431-469

Yunusa IA, Manoharan V, Odeh IO, Shrestha S, Skilbeck CG, Eamus D (2011) Structural and hydrological alterations of soil due to addition of coal fly ash. J Soils Sediments 11:423-431

Zahedi M, Rajabipour F (2019) Fluidized Bed Combustion (FBC) Fly Ash and Its Performance in Concrete. ACI Mater J 116(4)

Zhu Z, Wang X, Dai S, Huang B, He Q (2013) Fractional characteristics of coal fly ash for beneficial use. J Mater Civ Eng 25(1):63-69 